\title{
Spatio-Temporal Mapping of Plate Boundary Faults in California Using Geodetic Imaging
}

\author{
Andrea Donnellan 1,*, Ramón Arrowsmith ${ }^{2}$ and Stephen DeLong ${ }^{3}$ \\ 1 Jet Propulsion Laboratory, California Institute of Technology, Pasadena, CA 91109-8099, USA \\ 2 School of Earth and Space Exploration, Arizona State University, Tempe, AZ 85287-6004, USA; \\ ramon.arrowsmith@asu.edu \\ 3 United States Geological Survey, Menlo Park, CA 94025, USA; sdelong@usgs.gov \\ * Correspondence: andrea.donnellan@jpl.nasa.gov; Tel.: +1-626-797-8059
}

Academic Editors: Kevin Tansey, Stephen Grebby and Jesus Martinez-Frias

Received: 23 December 2016; Accepted: 13 March 2017; Published: 21 March 2017

\begin{abstract}
The Pacific-North American plate boundary in California is composed of a 400-km-wide network of faults and zones of distributed deformation. Earthquakes, even large ones, can occur along individual or combinations of faults within the larger plate boundary system. While research often focuses on the primary and secondary faults, holistic study of the plate boundary is required to answer several fundamental questions. How do plate boundary motions partition across California faults? How do faults within the plate boundary interact during earthquakes? What fraction of strain accumulation is relieved aseismically and does this provide limits on fault rupture propagation? Geodetic imaging, broadly defined as measurement of crustal deformation and topography of the Earth's surface, enables assessment of topographic characteristics and the spatio-temporal behavior of the Earth's crust. We focus here on crustal deformation observed with continuous Global Positioning System (GPS) data and Interferometric Synthetic Aperture Radar (InSAR) from NASA's airborne UAVSAR platform, and on high-resolution topography acquired from lidar and Structure from Motion (SfM) methods. Combined, these measurements are used to identify active structures, past ruptures, transient motions, and distribution of deformation. The observations inform estimates of the mechanical and geometric properties of faults. We discuss five areas in California as examples of different fault behavior, fault maturity and times within the earthquake cycle: the M6.0 2014 South Napa earthquake rupture, the San Jacinto fault, the creeping and locked Carrizo sections of the San Andreas fault, the Landers rupture in the Eastern California Shear Zone, and the convergence of the Eastern California Shear Zone and San Andreas fault in southern California. These examples indicate that distribution of crustal deformation can be measured using interferometric synthetic aperture radar (InSAR), Global Navigation Satellite System (GNSS), and high-resolution topography and can improve our understanding of tectonic deformation and rupture characteristics within the broad plate boundary zone.
\end{abstract}

Keywords: deformation; topography; earthquake

\section{Introduction}

For effective seismic hazard assessment, it is necessary to understand how plate motions are partitioned across the plate boundary zone and to characterize potential earthquake rupture sources within it. Plate tectonics drive the accumulation and release of strain either via earthquakes or via aseismic slip such as creep or anelastic bulk deformation, but how faults interact within the plate boundary can be complex. Earthquakes occur within systems of faults $[1,2]$ driven by plate tectonic motions. In this paper, we focus on the Pacific-North American plate boundary across California (Figure 1). We discuss deformation associated with repeated earthquakes and aseismic 
slip, concentrating on timescales of days to millennia. Initial deformation occurs quickly during and immediately following an earthquake. Tectonic motions can significantly reorganize the landscape as earthquakes occur over seismic cycles, leaving patterns in the land surface that reflect fault and geologic processes. Fundamental research questions about the landscape include: How do geopatterns on the Earth's surface arise and what do they tell us about processes? What are the transport laws that govern the evolution of the Earth's surface? [3]. Including understanding of landscape processes into interpretation of crustal deformation measurements enables a better assessment of the mechanisms contributing to deformation of the Earth's crust.

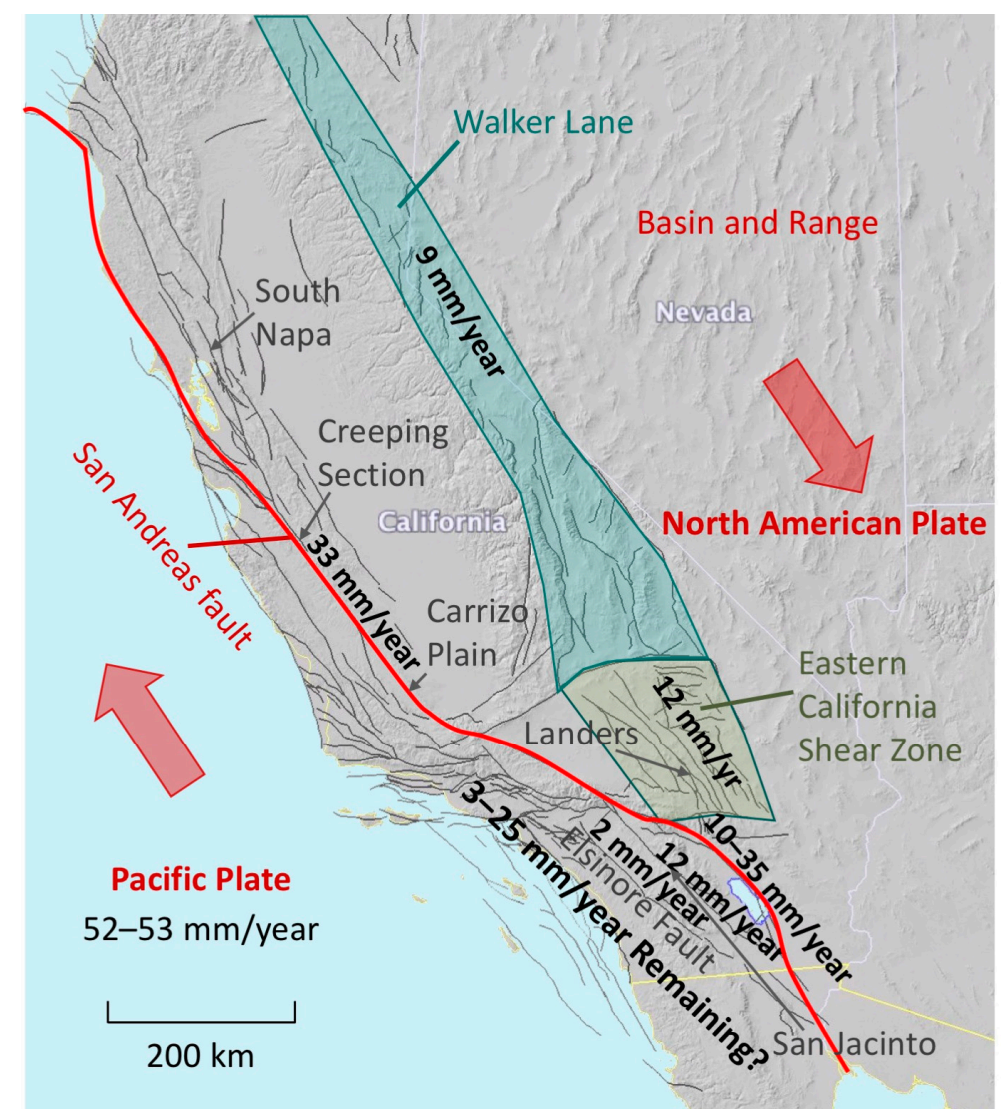

Figure 1. The Pacific and North America plate boundary accommodates a total relative plate motion of 52-53 mm/year [3,4]. The San Andreas fault (red line onshore) takes up most of the plate boundary motion of up to $66 \%$. About $25 \%$ of the plate motion is accommodated by the Eastern California Shear Zone in the Mojave Desert [4] and the Walker Lane to the north [5], leaving 9\% to be accommodated elsewhere. Estimated slip rate along the southern San Andreas fault has a wide range, representing substantial uncertainty. The estimated slip rate along the San Jacinto fault varies, but in this example we use $12 \mathrm{~mm}$ /year [6-8]. Slip rate along the Elsinore fault is approximately $2 \mathrm{~mm}$ /year [9] leaving a remaining 3-25 mm/year of deformation south of the Central and Western Transverse Ranges to accommodate the total plate motion. Numerous faults take up the entire plate boundary motion and the rates are more uncertain than the simplified model shown here.

Our motivation is to review emerging methods that allow for improved spatio-temporal understanding of fault zones and to call for new, more holistic, approaches to high-resolution topographic mapping of the entire greater San Andreas fault (SAF) system and beyond. We argue that it is necessary to infer slip distribution and rheologic properties at local and plate boundary scales in order to assess earthquake hazard, and that these properties are reflected in topography and crustal deformation. Faults connecting from the upper crust to deeper plate boundary motions 
and measurement at multiple scales best addresses the above questions. Measurement of crustal deformation and surface morphology can be accomplished by broader deployment of existing methods including synthetic aperture radar, lidar and Structure-from-Motion (SfM) from small unmanned aerial systems (sUAS) and by development of new airborne and spaceborne platforms to deploy next generation SAR, laser, and multispectral mapping technology. We focus on five distinct areas within the California Pacific-North American plate boundary to illustrate these processes.

The characteristics of plate boundaries include tectonic features on spatial scales ranging from local sub-meter rock damage zones and surface faulting, to kilometer-wide fault zones, and networks of faults hundreds of kilometers wide. Understanding the system of faults within a plate boundary is necessary to better forecast earthquakes. No predictable pattern of where or when the next earthquake will occur in a sequence of events has emerged. Earthquakes can occur sequentially along sections of a fault such as the 1939-1999 North Anatolian earthquake sequence $[10,11]$ or between different faults such as occurred for the $1992 \mathrm{Big}$ Bear/Landers earthquake sequence [12]. Seismic hazard analysis combines statistical analysis of seismicity, geodetically measured strain accumulation, historical earthquakes, and records of prehistoric earthquakes preserved in the geologic record. In an ideal case, the moment release from earthquakes exactly matches the strain accumulation from plate tectonics. However, geodetic imaging, broadly defined as measurement of crustal deformation and topography of the Earth's surface, indicates two complicating factors: (1) rates of deformation change over multi-year timescales and can switch modes, particularly after large earthquakes [13], such as from horizontal shortening to lateral shear; and (2) off-fault and aseismic deformation may account for a significant amount of total plate boundary motion.

Earthquake rupture characteristics are largely controlled by the geometry of fault networks. Earthquake magnitude correlates with earthquake rupture length [14]. Earthquake rupture propagation can be inhibited by barriers [15] or steps between fault segments [16]. Faults may be rooted to a single fault at depth but split into strands at the near surface in a flower structure [17]. The geometry of fault zones, the partitioning of deformation between seismic, aseismic and postseismic slip, and the nature of fault damage may be reflected in the topographic features of fault zones $[18,19]$. Here, we present three unresolved questions to argue that multiple scale measurements using different types of geodetic and geologic measurements are necessary to better understand earthquake processes. These are: (1) How do plate boundary motions distribute across California faults? (2) How do faults within the plate boundary interact? (3) What fraction of strain accumulation is relieved aseismically? We propose that observations at scales of fault zones $(\mathrm{m})$, fault systems $(\mathrm{km})$, and plate boundaries $(10 \mathrm{~s}-100 \mathrm{~s}$ of $\mathrm{km})$ can reveal the spatio-temporal factors controlling earthquake processes, and we discuss approaches to multi-scale measurement and observation that may characterize the importance of geometry and kinematics to infer of mechanical processes.

\section{Materials and Methods}

Several methods exist to measure velocities and strain rates at or near the surface of the Earth. We focus here on characterization of crustal deformation using geodetic measurements from GPS, airborne radar interferometry, and high-resolution topography from multiple collection platforms. Other methods used to characterize crustal deformation include spaceborne InSAR, leveling, triangulation and trilateration, borehole or laser strainmeters, and paleoseismology. The measurements are used to infer processes at depth by inverting the data or constructing forward models. For topographic measurements, we focus on ground and airborne lidar and Structure from Motion (SfM) photogrammetric measurements from small sUAS [20]. These measurements are complementary, capturing a wide range of spatial and temporal scales of crustal deformation and landscape evolution.

\subsection{GPS}

Global Positioning System (GPS) measurements provide precise position time series from which velocities from plate tectonic or other motions or displacements from earthquake can be 
determined [21]. GPS data for measuring crustal deformation were originally collected infrequently at a sparse set of stations in southern California [22,23]. As an example of early demonstration of the value of GPS measurements, modeling of deformation determined from GPS combined with triangulation measurements suggested that buried thrust faults bounded and dipped away from the Ventura basin [24]. The fault that ruptured in the subsequent 1994 M6.7 Northridge earthquake [25] was consistent with that identified through modeling the GPS measurements. In the following decade, a continuous network of about 250 GPS stations was implemented throughout Southern California [21]. This was followed by the Plate Boundary Observatory [26], which is part of the NSF-funded EarthScope program to explore the four-dimensional structure of the North American continent, and consists of about 1100 continuous GPS stations in the western United States [27].

Station spacing of the Plate Boundary Observatory continuous GPS network across the active faults of the plate boundary is on average about $10 \mathrm{~km}$. In California, the Pacific-North American plate boundary is about $400 \mathrm{~km}$ wide, which means that at any given latitude about 40 GPS span the width of the zone. The GPS stations are generally concentrated closer to fault zones and sparser in less tectonically active areas such as the Central Valley of California. The accuracy of GPS measurements is about $1 \mathrm{~mm}$ /year for horizontal velocities [6] and about a factor of two lower for vertical velocities [28]. The daily position time series provide a high data rate for detecting slip from earthquakes, postseismic motions, and any other transient motions, such as subsidence from fluid withdrawal [29] which occur on timescales of months to years. Surface deformation measurements generally indicate fault motion at a depth on the order of the distance of the point of measurement from the fault [30]. That means that for $10 \mathrm{~km}$ station spacing for a fault that is creeping at depth, it is not possible to accurately determine the locking depth of the fault. In order to understand whether or by how much faults creep in the near surface, crustal deformation must be sampled at a much denser spacing.

\subsection{InSAR}

Interferometric Synthetic Aperture Radar (InSAR) uses differences between two images to produce a map of line of sight changes between points on the ground and the airborne or spaceborne instrument [31,32]. Measurement of displacements from an earthquake requires before and after images. The images are compared and if the ground has moved and the instrument repeats the image from the same place, the waves interfere producing a map of fringes that represent line of sight phase and thus range changes. The first SAR image of an earthquake was produced by the European Radar Satellite (ERS-1) for the 1992 M7.3 Landers earthquake [33]. An advantage of InSAR over GPS measurements is the spatial continuity of the measurements. The time between images can range from weeks to years, which means that InSAR typically does not capture rapid deformation processes. Furthermore, InSAR produces line of site measurements, so unless images from multiple vantage points are collected, decomposing the results into component horizontal and vertical motions requires constraints from field observations or GPS vector displacements.

Spaceborne InSAR data have been available from a variety of orbiting spacecraft and more are planned, including the NASA-ISRO Synthetic Aperture Radar (NISAR) mission [34] scheduled to launch in late 2021. Since 2009, NASA has operated UAVSAR, an airborne InSAR instrument that is mounted underneath a Gulfstream-III aircraft [35-37]. UAVSAR is an L-band instrument that images a $15 \mathrm{~km} \times 90 \mathrm{~km}$ swath, and it has been operational since 2009 (Figure 2). It has been deployed globally, but the main focus has been in California where it supports a number of investigations. UAVSAR has been used to image deformation after three earthquakes ranging in magnitude from 5.2 to 7.2 [38-40]. UAVSAR produces images with $1 \mathrm{~m}$ spatial resolution for phase change images and $7 \mathrm{~m}$ for images that have been unwrapped. Unwrapped images convert the phase changes to line of sight range changes between the ground surface and the instrument. If the surface is too disrupted, the phases decorrelate and it is not possible to construct an image of phase changes in that disrupted area. 


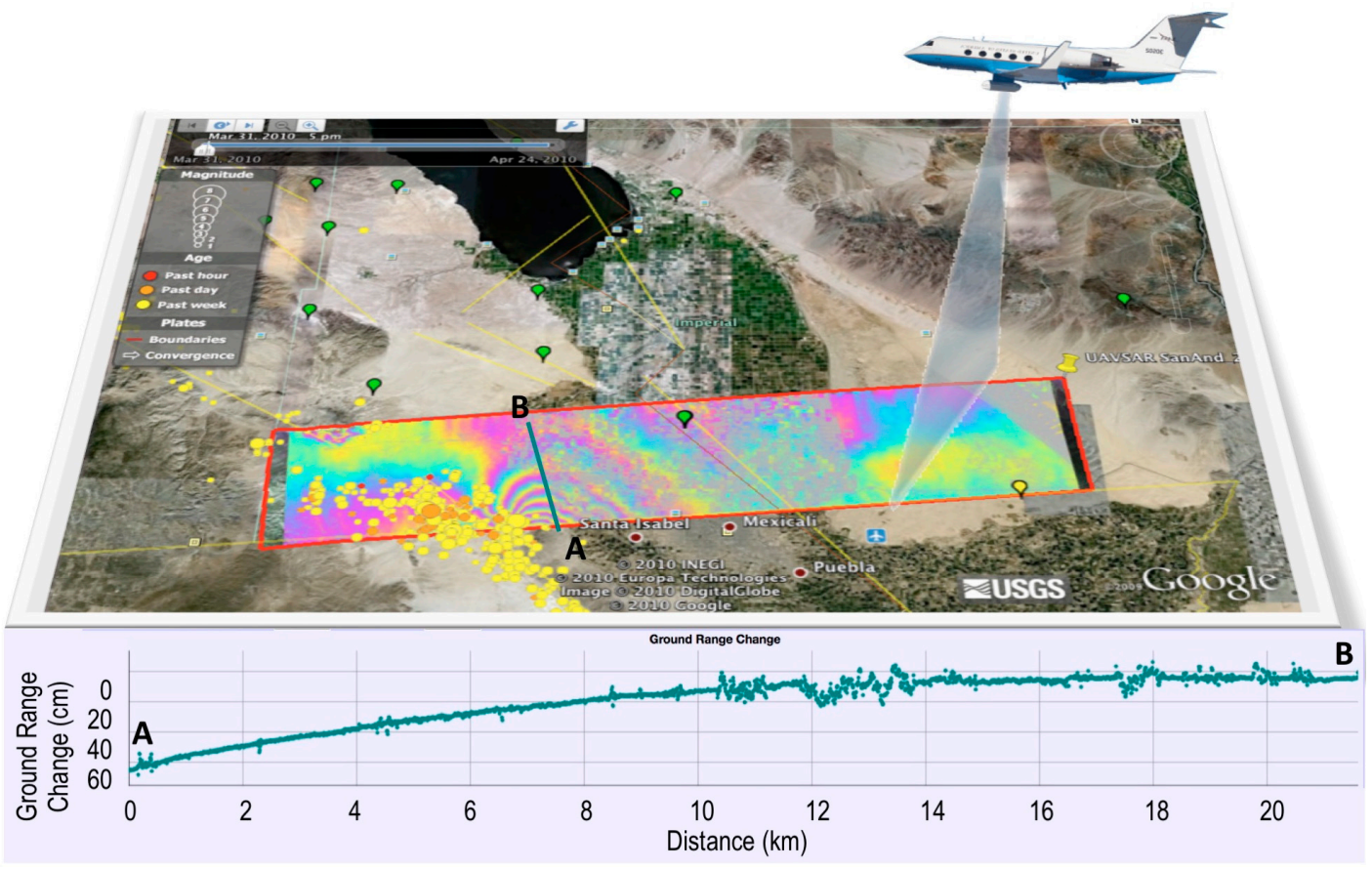

Figure 2. UAVSAR concept showing the airborne instrument. The oblique image is of the Salton Trough in southern California. The south (bottom) edge of the UAVSAR image lies at the US-Mexico border. The yellow dots represent aftershocks from the 2010 M7.2 El Mayor-Cucapah earthquake. The Salton Sea is shown at the north end of the image bounds the Imperial Valley. The width of the swat is about $15 \mathrm{~km}$. The lobes of fringes represent about $60 \mathrm{~cm}$ of differential motion in the crust north of the main rupture as shown by the extracted ground range change in the profile plot with the location noted on the interferogram [38].

\subsection{Topography}

The Earth's surface is the interface between geomorphic and tectonic processes. Geomorphic processes act to change elevation through erosion and deposition while tectonic processes translate, depress and/or elevate the surface directly. At larger spatial scales, topography indicates cumulative interactions across mountain ranges, such as the balance of accretionary and erosional fluxes [41], for example, as manifest by bedrock channel forms [42]. Differential motions over hundreds of kilometer wavelengths are driven by variations in mantle buoyancy to produce "dynamic topography" (e.g., [43]). Investigations of active faulting, on the other hand, may require large ranges in inner and outer length scales. For example, an M8 earthquake may be $400 \mathrm{~km}$ in length, but the bulk of the displacements occur within a $1 \mathrm{~km}$ wide zone and fine displacements and geomorphic responses are at decimeter or finer scales. Topographic-based investigations of faulting include fault trace mapping, reconstructing slip histories, understanding geomorphic response to uplift, and 3D topographic differencing (e.g., [44-46]).

A major challenge is to acquire, handle, and process the right topographic data in time, space, and sampling density for the question. 3D heterogeneous sampling of a point cloud is distinct from 2D or "2.5D" regular or gridded samples from digital elevation models (DEM). The surface is generally defined as a digital surface model (DSM) for the first case and the inferred ground surface digital terrain model (DTM) for the second. Many space-based platforms provide global to regional DSM coverage with 10-100 m per pixel such as the Shuttle Radar Topography Mission [47], ASTER GDEM [48,49], Global Multi-Resolution Topography (GMRT), which includes bathymetry [50], TanDEM-X [51], etc. At local to site scales, topography is sampled with $\mathrm{cm}$ to meter/pixel, tends towards 3D representations, and is acquired from airborne, mobile, and ground-based platforms. This centimeter to decimeter sampling is essential for representing faulting and surface processes. Topographic data are thus 
collected from a range of platforms with increasingly finer resolutions, greater accuracy, and shorter repeat times. Understanding faulting processes requires the ability to discover, manage, share, and process topographic data. Community cyberinfrastructure increases the impact of investments in topography data and catalyzes scientific discovery (see for example, OpenTopography [52]).

\subsubsection{Lidar}

Laser scanning from airborne, mobile, and terrestrial platforms is the current benchmark method for acquiring topographic data of sufficient resolution to resolve fine scale fault zone features and to track crustal motions in three dimensions through time [53]. Airborne data are generally collected from fixed-wing or rotary blade aircraft and produce data with decimeter scale accuracy and sub-meter scale spatial resolution and are only partially hindered by vegetation [54]. Mobile data are gathered from vehicles, backpack systems and low airborne platforms such as balloons or sUAS and provide data with centimeter scale accuracy and precision. Terrestrial data are collected from stationary tripods, generating data with sub-centimeter scale accuracy and resolution.

While there are examples of widespread lidar coverage from airborne platforms (e.g., [55]), it remains expensive to map at the plate boundary scale and significant data gaps remain. The promise of repeat coverage over large spatial scales to quantify Earth surface changes through time is not possible given current priorities and resources. This challenge is exemplified by the limited progress towards nationwide coverage in the United States via the U.S. Geological Survey 3D Elevation Program [56].

Despite limitations in the use of lidar for understanding plate boundary process, several examples are indicative of the promise of remotely sensed topographic measurements to understand specific tectonic settings and processes. Coseismic deformation patterns of several earthquakes have been constrained using multitemporal airborne lidar data. These include the 2010 M7 El Mayor-Cucapah earthquake [57,58], the 2008 M6.9 Iwate-Miyagi Nairiku (Japan) and 2011 M7.1 Fukushima Hamadori (Japan) earthquakes [59], and the 2010 M7.1 Darfield (New Zealand) earthquake [60]. These earthquakes all had meter-scale near-field deformation, so could be quantified using airborne data that tend to have decimeter scale accuracy and resolution, but finer scale and more distributed deformation remains difficult to quantify with airborne lidar. We do however anticipate scientific response to recent and imminent large continental earthquakes will generate new studies reliant on repeat airborne lidar at progressively higher levels of detail.

Finer-scale deformation can be quantified using terrestrial and mobile lidar, but over somewhat limited spatial scales. Mobile laser scanning (e.g., [61]) has advantages over airborne lidar in speed of deployment and level of resolution, and over terrestrial methods in its ability to survey significantly larger areas fairly quickly but ground-based systems are more limited by vegetation cover than airborne systems.

Several studies have employed terrestrial laser scanning to quantify plate boundary process and to map fault zones. These include the 2004 M6.0 Parkfield, California earthquake; the 2004 M6.6 Niigita Ken Chuetsu earthquake in Japan [62]; the 2010 M7 El Mayor-Cucapah earthquake in Baja California, Mexico [63]; the 2009 M6.3 L'Aquila earthquake in Italy [64]; and the 2014 M6.0 South Napa earthquake $[40,65]$.

Here we review a few published and previously unpublished studies that report on the use of remotely-sensed topographic data from laser scanning to study plate boundary processes. For more complete descriptions of the processing required to acquire and analyze these data, we direct the reader to a recent review of lidar and other high-resolution topographic data [53], and, for an example of terrestrial laser scanner collection and processing, a recent study of surface rupture associated with the South Napa earthquake [65].

\subsubsection{Structure from Motion (SfM)}

The advent of inexpensive digital cameras, sUAS, and fast computer processing power has enabled rapid growth in modeling three-dimensional structure from photographs. Using SfM, images can be 
combined to solve for surface topography (e.g., [20]). Advantages of SfM over traditional airborne stereo imaging is the ability to image steep slopes, to capture topography from a wide range of sensors without detailed flight planning and the ability to resolve very fine-scale features (Figure 3). Structure from motion also produces colored 3D models from the imagery, which can provide information about lithology and surficial characteristics (e.g., vegetation, moisture, texture, structure).
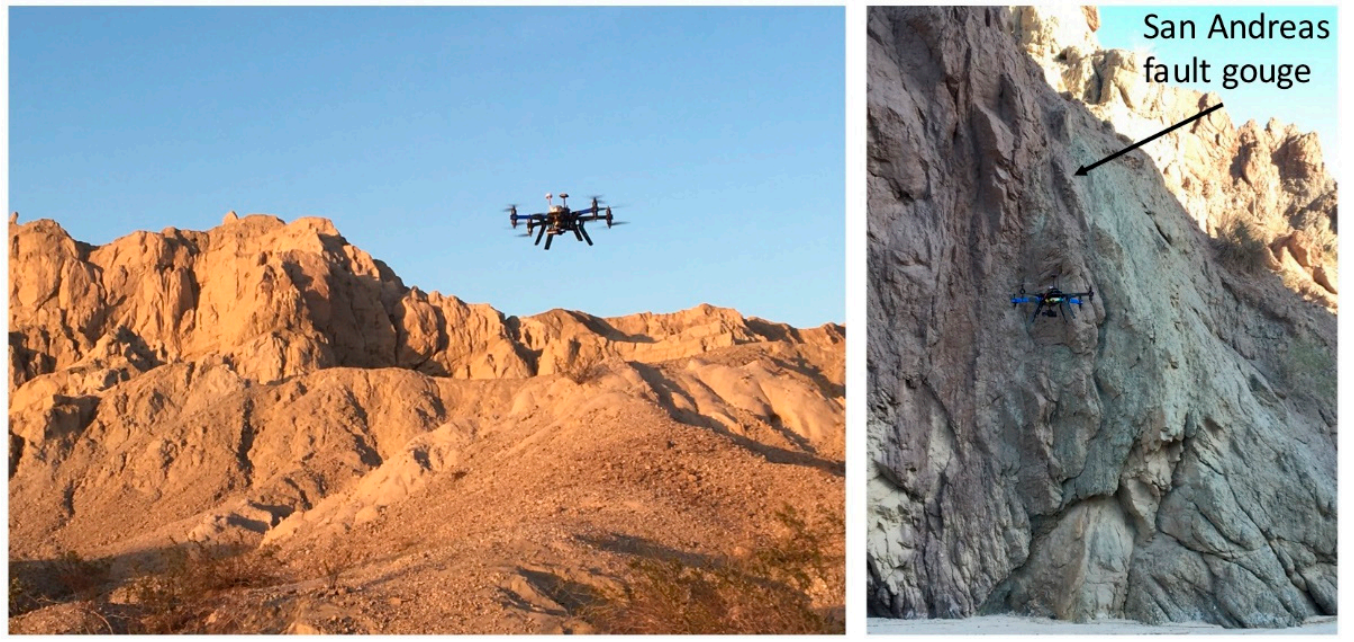

Figure 3. Example flight of a small unmanned aerial system (sUAS): in the Mecca Hills (left); and in Painted Canyon (right), acquiring low-altitude photos and to apply Structure from Motion along the San Andreas fault. The sUAS can image steep slopes to create topographic reconstructions with comparable horizontal and vertical resolution.

\section{Results}

GPS velocity measurements are useful for understanding how deformation is distributed across the California plate boundary. Grand inversions have been carried out to estimate earthquake slip and timing along hundreds of sections of fault throughout California [1]. Knowledge of these details of slip is important for informing estimates of earthquake hazard. Identifying the dominant fault zones is important for inferring details of the plate boundary at depth within the lithosphere.

Crustal blocks are surrounded by actively deforming zones in California (e.g., [6,66-68]). A simple exercise suggests that two zones of shear dominate in California. We plotted velocities in California relative to GPS stations near the SAF and in the Owens Valley (Figure 4). In those reference frames, GPS velocities to the west of the reference station move northward and stations to the east move southward. The inflection between northward and southward velocities can be traced as a zone of shear. These two zones join at the Gulf of California. Moving northward from there, one zone follows the San Jacinto fault, joining with the SAF to the north. The second zone follows the southernmost Coachella segment of the SAF and connects through the Eastern California Shear Zone and the Walker Lane. The zone of deformation is narrower, on the order of $10 \mathrm{~km}$, along the more mature central SAF than it is to the south where it is about $40 \mathrm{~km}$ wide, or in the northern Walker Lane where it is about $50 \mathrm{~km}$ wide. These two zones likely represent deep lithospheric shear where the plate boundary transitions from the SAF system which is oblique to the overall plate boundary and therefore not oriented ideally within the overall stress field, to the more plate-boundary-parallel Eastern California Shear Zone. Dominant shear zones in California likely correlate with compliant zones between crustal blocks and may point to zones of lithospheric weaknesses. Measurement of surface deformation is necessary to drive models of lithospheric processes with heterogeneous mechanical properties.

In what follows, we sample locations along these plate boundary zones beginning at the northern end of the San Andreas branch of the Pacific-North American Plate boundary. We present key characteristics of the immature South Napa earthquake fault, the creeping section of the SAF, and the 
mature SAF in the Carrizo Plain. We discuss geomorphic modifications to the Landers earthquake rupture in the Eastern California Shear Zone. To the south, where these two zones merge, we discuss the locked San Jacinto fault, the intermittently creeping southern SAF, and the network of faults in the Salton Trough where these two major faults terminate.
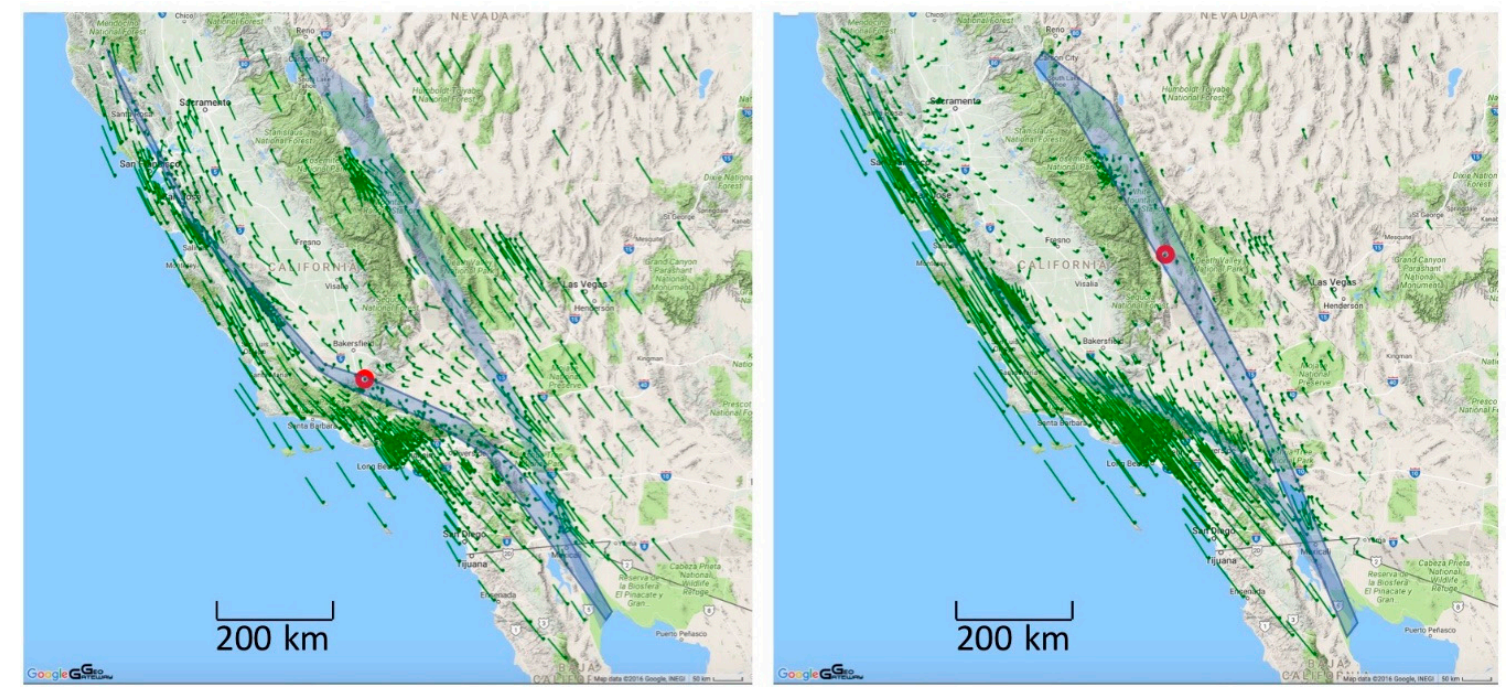

Figure 4. Global Positioning System velocity vectors are plotted relative to two different stations using GeoGateway $[69,70]$. Stations are marked by a small circle and a line with no arrowhead represents the velocity vector. Left panel shows velocities relative to station EDPP [71] near Tejon Pass noted by a red circle. Right panel shows velocities relative to station P093 in the Owens Valley, also noted by a red circle. The dividing region between northward and southward vectors was drawn in for: the San Andreas fault (left); and Eastern California Shear Zone/Walker Lane (right), and then plotted on each map.

\subsection{South Napa Earthquake-Moderate Rupture through Several Mapped and Unmapped Traces}

The Mw 6.0 South Napa earthquake of 24 August 2014 caused slip along several active fault strands within the West Napa fault zone. Field mapping identified $12.5 \mathrm{~km}$ of surface rupture and analysis of airborne UAVSAR data indicated more than $\sim 30 \mathrm{~km}$ of surface deformation with a relatively complex distribution across a number of subparallel lineaments [43]. Postseismic slip exceeded coseismic slip along a portion of the main rupture trace, and maximum summed postseismic and coseismic slip approached $0.5 \mathrm{~m}$ [43]. A primary challenge after the earthquake was rapid and accurate surface rupture mapping, quantification of coseismic slip, and subsequent identification and monitoring of potentially damaging postseismic slip [72]. Analysis of UAVSAR data provides slip distributions along multiple fault traces, indicates connectivity and extent of secondary traces, and confirms that postseismic slip only occurred on the main trace of the rupture [40].

Of particular interest is the use of lidar, photography, and UAVSAR to map the fault rupture and image the fault zone. Figure 5 displays a section of the fault zone imaged using air photos, airborne lidar and terrestrial lidar. This highlights the challenge of mapping fine scale tectonic features and the need for topographic and imagery data with submeter and finer spatial resolution. Though vertical deformation over the coseismic interval was measureable using repeat airborne lidar, and some coarse estimations of horizontal measurement were made using repeat airborne lidar [72,73] the most precise (but spatially limited) quantifications of horizontal slip magnitudes were made during the postseismic interval using terrestrial lidar [65,74]. Figure 6 displays results from identifying geometric primitive objects from terrestrial lidar point clouds and tracking them through time. Because the earthquake was moderate in magnitude and in amount of surface rupture and deformation, this level of detection 
required data with centimeter level accuracy and precision acquired over multiple survey epochs. Larger earthquake deformation in contrast may be adequately quantified using somewhat coarser data.
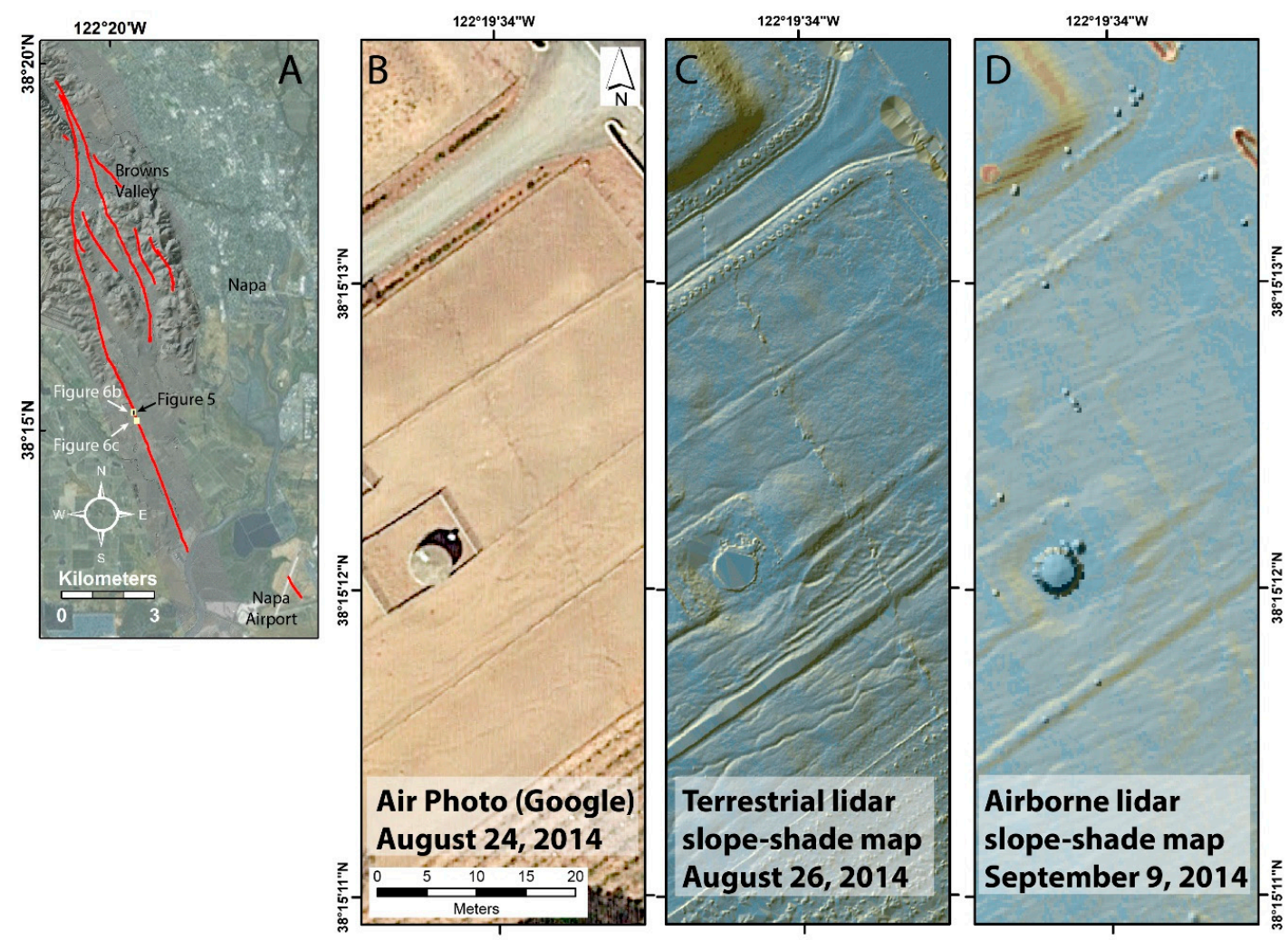

Figure 5. Images from 2014 South Napa Earthquake: (A) map of surface rupture with location of zoomed panel; (B) orthorectified air photos with $\sim 30 \mathrm{~cm}$ pixel resolution collected the day of the earthquake by Google; (C) slope-shade map with $2.5 \mathrm{~cm}$ pixel resolution made from a digital elevation model generated from an ultra-high resolution 3D point cloud $\left(>1000\right.$ points $\left./ \mathrm{m}^{2}\right)$ from a terrestrial laser scanner; and (D) slope-shade map with $25 \mathrm{~cm}$ pixel resolution made from a digital elevation model generated from a high resolution $\left(\sim 20\right.$ points $\left./ \mathrm{m}^{2}\right) 3 \mathrm{D}$ point cloud from an airborne laser scanner survey. Figure modified from [43]. In each panel, the rupture cuts the image from the lower right corner up towards the upper left corner.

As a tool to map the distribution of surface deformation, UAVSAR proved to be particularly valuable. UAVSAR interferograms were used iteratively with field observation to understand the distribution of surface deformation. Furthermore, UAVSAR provided the most robust means of generating full coseismic and postseismic slip distributions [40] (Figure 7). The wrapped interferogram shows considerable surface disruption, but the product is useful for identifying the location of fault rupture from discontinuities in the image. However, the severe surface disruption caused decorrelation in a zone about $4 \mathrm{~km}$ wide for the unwrapped interferogram. A combination of field measurements and displacement determined from the unwrapped interferogram were used to estimate fault slip.

The South Napa earthquake occurred within a low slip rate fault zone containing a network of what may be considered immature faults due to their complex connectivity and weak surface expression [75]. The surface rupture was located 2-2.5 km west of the part of the mapped West Napa fault trace thought to be most active [43]. Both faults lie within a series of nearly parallel faults in a $100 \mathrm{~km}$ wide plate boundary zone. It is interesting to note that South Napa rupture lies within the shear zone identified with GPS velocities (Figure 2). The shear zone connects to the south with the Calaveras fault and then joins the SAF at the north end of the creeping section of the SAF. The question remains how this system of parallel faults roots to the plate boundary at depth. 


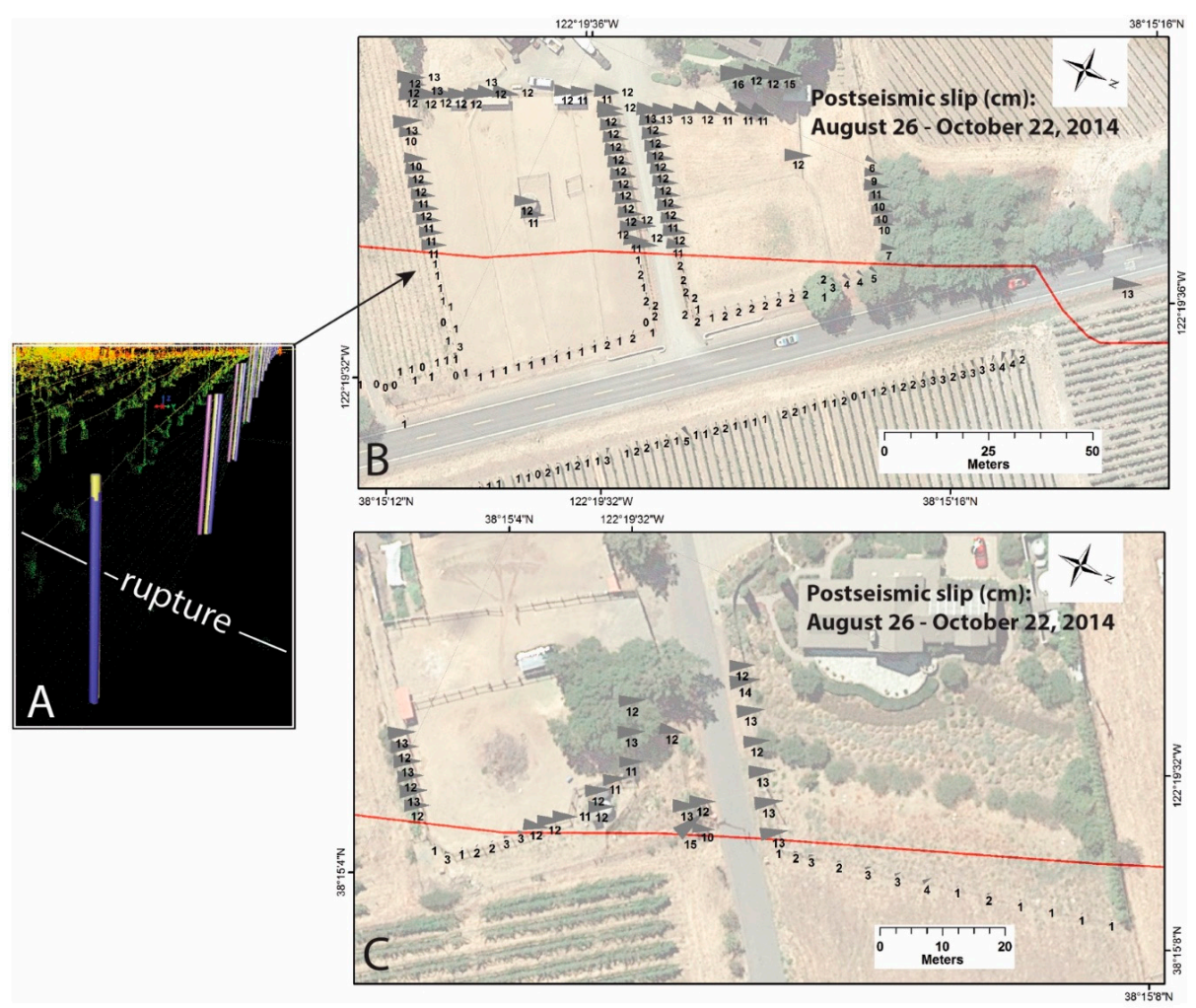

Figure 6. Postseismic deformation associated with 2014 South Napa earthquake as measured using objects in terrestrial lidar point cloud. (A) Cylinders modeled from fence posts in point clouds at three times post-earthquake, and 3D point cloud of vineyard rows in background. Note the progressive dextral offset relative to the fencepost in the foreground. $(\mathbf{B}, \mathbf{C})$ Display direction (grey arrow) and amount of translation of objects in the study area (as indicated by the size of the arrows and their labels), which are translation distances in $\mathrm{cm}$. Red line indicates the generalized trace of the 2014 surface rupture. Base image is aerial photograph taken 24 August 2016 by Google. Figure modified from [67]. Study area locations are shown in Figure 5.

\subsection{Creeping Section of the $S A F$}

The 175-km long creeping segment of the SAF from Parkfield, California in the south to San Juan Bautista in the north is thought to prevent rupture propagation from the southern SAF to the northern SAF, effectively limiting the possible moment release on the greater San Andreas System. However, the possibility of significant coseismic moment release along the creeping segment remains a point of discussion in the literature [76,77] and is included in seismic hazard models, albeit with low probabilities [1]. As such, it remains critical to determine the distribution of relative plate motion across the SAF system along this fault section. This requires measuring and mapping the spatial and temporal distribution of aseismic slip in order to identify any slip deficit that might indicate potential for coseismic moment release. Aseismic slip rate varies along the creeping segment and also when measured over different apertures [78,79], but these measurements alone do not allow for proper slip partitioning onto mappable structures and/or distributed deformation [80]. Detailed fault mapping from field [81] and remote sensing (lidar) mapping [82,83] begin to explain the nature of the fault in a particularly complex zone of distributed faulting. Deformation may be accommodated along the creeping SAF as discrete fault offset only or with additional distributed deformation [80]. The question of whether plate boundary motion is accommodated as distributed deformation or accumulated as elastic strain or fault zone slip is fundamental to understanding rupture propagation and potential earthquake magnitude in central California. However, these studies do not constrain the motions or properly partition aseismic slip across multiple structures and/or measure distributed deformation 
between mappable structures. This can be addressed by combining UAVSAR, GPS, and collection of new geodetic imaging from sUAS and lidar platforms.

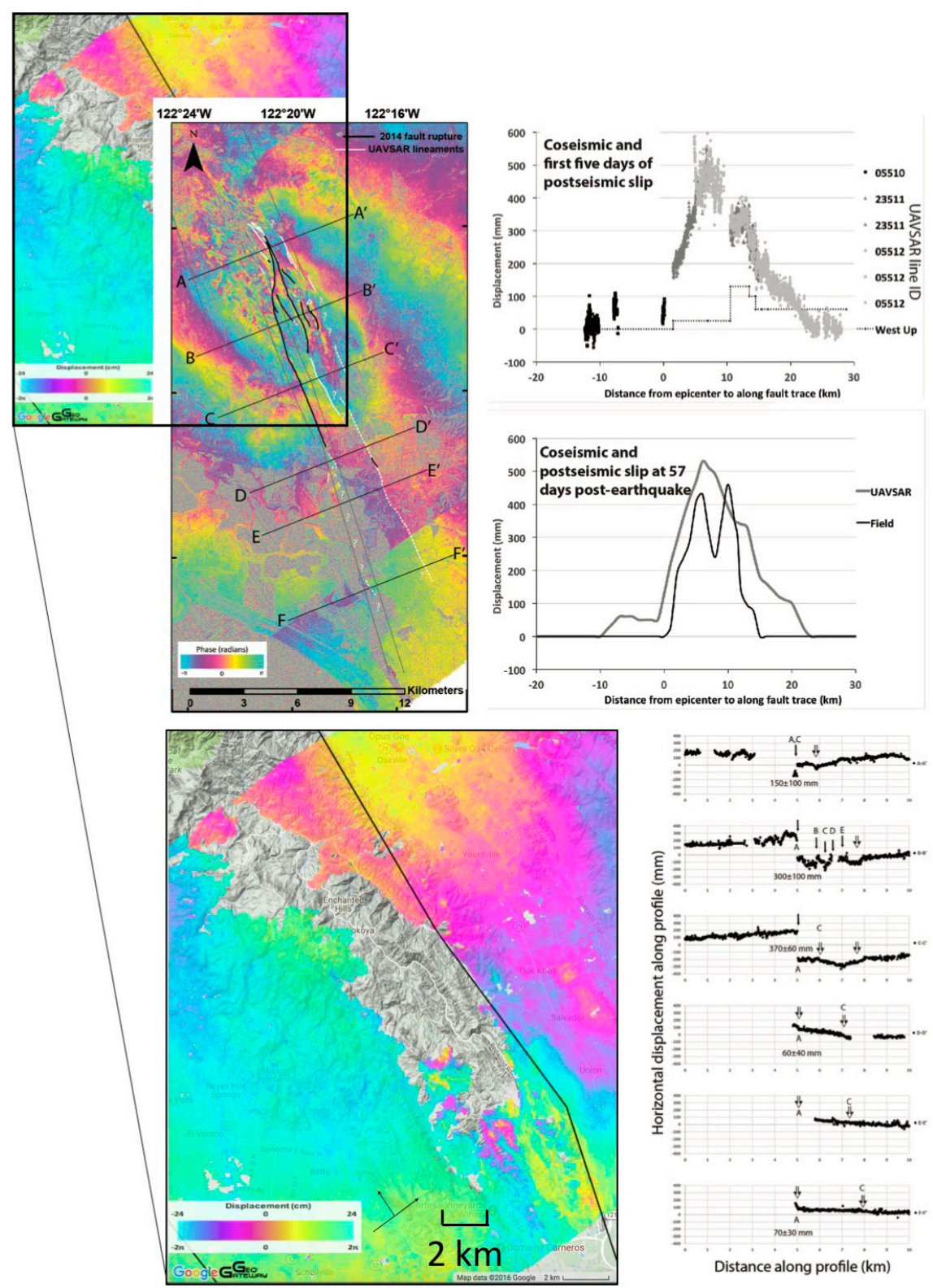

Figure 7. Deformation measurements from 2014 South Napa earthquake. Far upper left image places bottom image in context of top image, which shows interpreted UAVSAR interferograms with field-observed surface rupture in black and UAVSAR-interpreted deformation in white. Lines 05510, 23511, and 05512 are shown. The seams between images appear as discontinuities. Top right pane indicates event slip distribution from field study and UAVSAR analysis. Lower left panel shows unwrapped interferogram for line 05512 with decorrelated region. Mapped fault is shown as a black line from UCERF-3 [1]. Lower right panel displays horizontal displacements along selected profiles marked on top left image. Figure modified from [43].

Preliminary comparison of air and ground based lidar measurements from 2007 and 2016 respectively on the creeping section of the SAF constrain horizontal creep across the fault zone. At Mee Ranch along the creeping SAF, an alignment array with an aperture of 200 meters provided a near-field slip rate of $23.7-26.5 \mathrm{~mm} /$ year $[79,81]$. A reconnaissance-level application of lidar differencing is 
generally consistent with this result (Figure 8). The quantitative relationship between slope along a fault-parallel cross-section and local vertical difference gives the relative horizontal motion. The value of $31.2 \pm 12 \mathrm{~cm}$ in nine years, gives a rate of $35.2 \pm 11 \mathrm{~mm} /$ year for the past nine years, at the higher end of previously reported values, but over a greater width and with greater error bars than the alignment array data presented in [81]. An offset fence can be seen in the sUAS observations (Figure 8D). The main zone of creep is about $2 \mathrm{~m}$ wide as is evident from the deformation of the fence. This preliminary analysis motivates further development of analyses capable of producing creep and deformation measurements from topographic data.
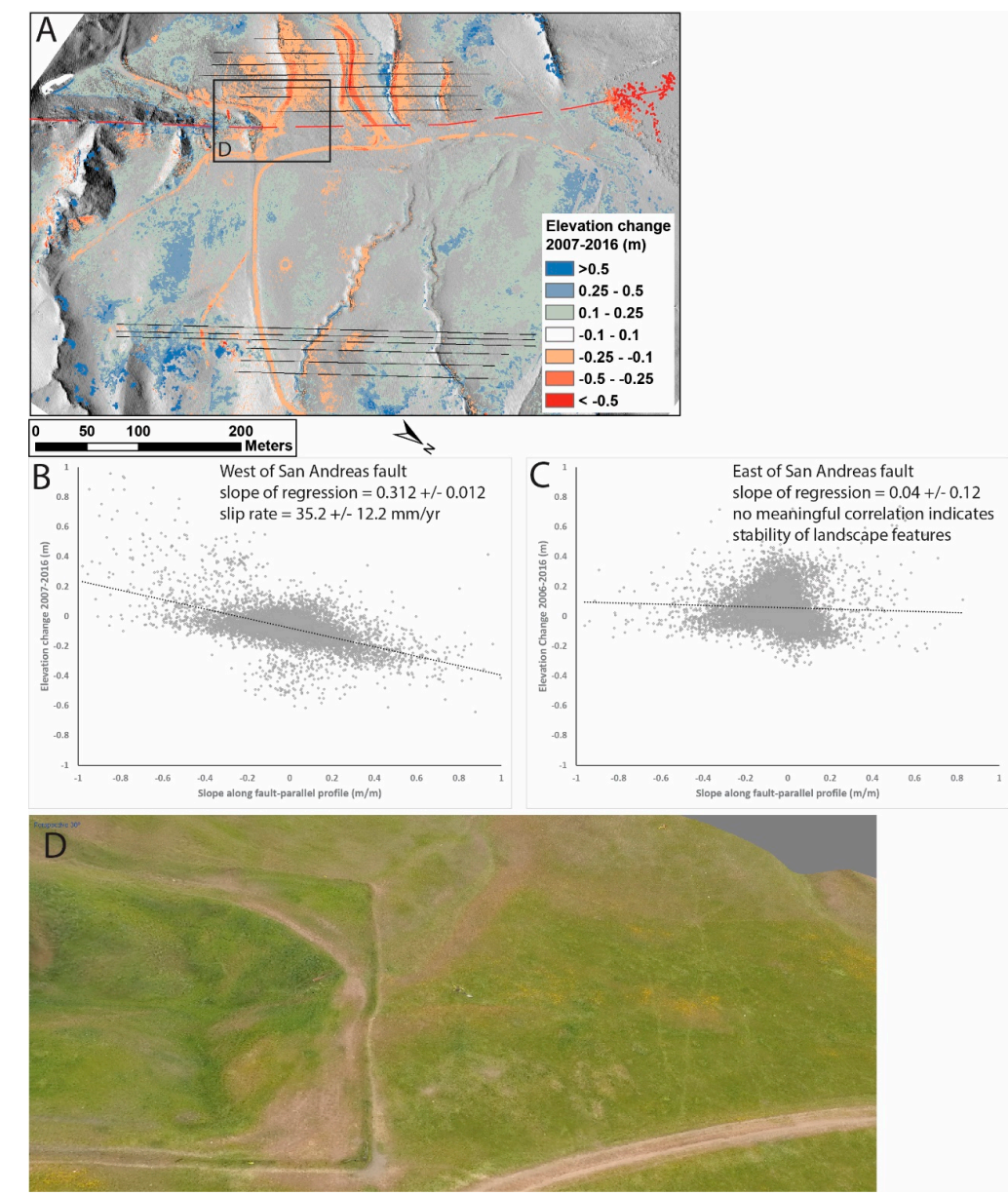

Figure 8. Rapid slip rate estimation from topographic change. (A) Map of elevation change from 2007 to 2016. This map displays vertical difference between 2007 airborne lidar and 2016 terrestrial lidar determined in a east-side-stable reference frame. Red indicates elevation decrease. Elevation decrease along south-facing slopes on west side of fault (top of figure) and elevation increase along north-facing slopes on west side of fault indicate dextral motion. (B,C) Plots of local fault-parallel slope versus elevation change on west and east sides of fault, respectively. These are taken from six fault parallel profiles on each side of fault as mapped in (A). For relatively smooth slopes and small slip magnitudes, the relationship between slope along a profile in the direction of fault motion and the vertical difference in elevation at that point at two times indicates the amount of horizontal movement. In this case, the slope of the regression line of slope versus elevation change along several fault-parallel profiles provides the amount of interseismic creep on the San Andreas fault from 2007 through 2016. In this case, the apparent horizontal offset is $0.312 \pm 0.12 \mathrm{~m}$ over nine years, indicating a slip rate of $35.2 \pm 11.2 \mathrm{~mm} /$ year, consistent with the higher end of previous estimates [81]. (D) 3D topographic model from sUAS-derived Structure from Motion photogrammetry. A fence offset by aseismic slip on the SAF is clearly visible just left of center. The fault cuts from left to right through the middle of the image. 
UAVSAR observations over 1.73 years indicate a rate averaged between the cross and along fault difference profiles of about $32.5 \pm 21 \mathrm{~mm}$ /year of horizontal motion if we assume that all of the motion is horizontal (Figure 9). The error is similarly large to the preliminary lidar analysis. The zone of deformation is about $200 \mathrm{~m}$ wide, however, suggesting additional off-fault deformation beyond the aperture of the alignment arrays, but within the aperture of the lidar analyses, with the possibility of additional off-fault deformation. The lack of UAVSAR data products for multiple look directions makes it difficult to separate horizontal from vertical motion here, which could also account for the possible differences among analytical results. GPS measurements show $27 \pm 1 \mathrm{~mm} /$ year, $28 \pm 1 \mathrm{~mm} /$ year, and $29 \pm 1 \mathrm{~mm} /$ year for 1,7 , and $20 \mathrm{~km}$ GPS station spacing across the fault. The more recent lidar and UAVSAR measurements are more consistent with, but still larger than the farther field GPS results, than with the earlier alignment array measurements, leaving open the question whether measurement bias or time varying slip accounts for the discrepancy.
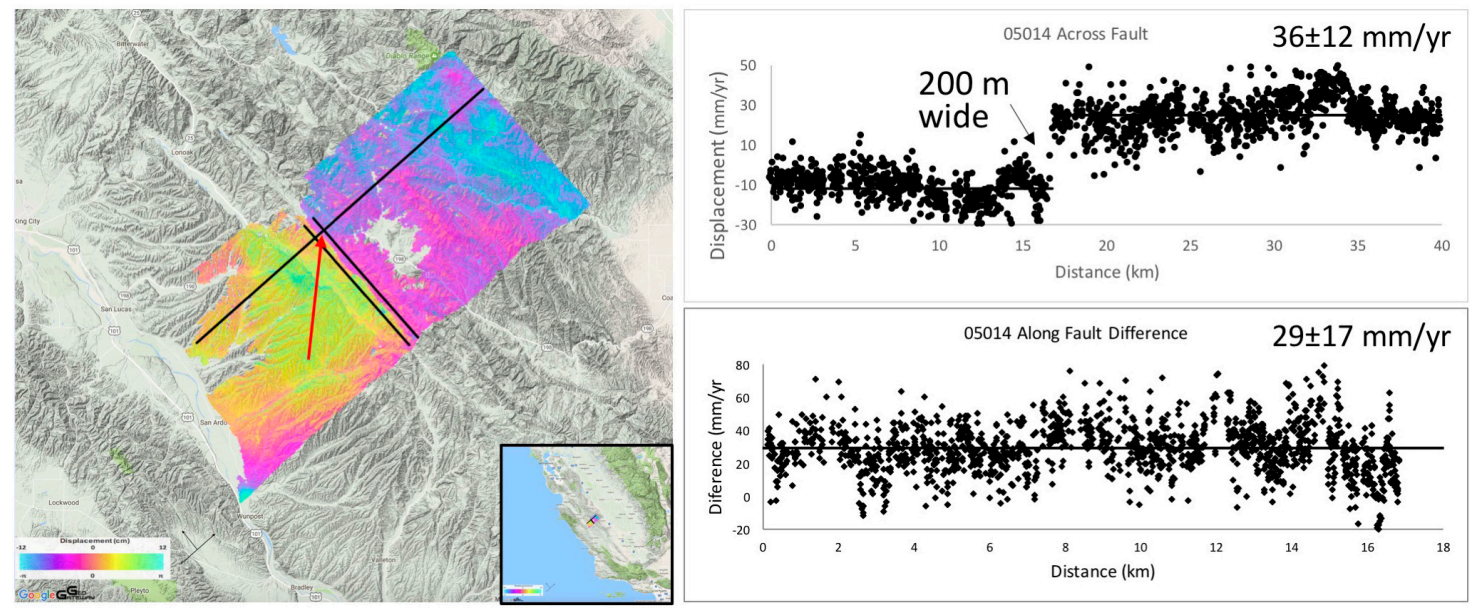

Figure 9. UAVSAR line SanAnd_05014_09009-001_10082-006_0630d_s01_L090HH_01 for data collected 26 February 2009 and 18 November 2010. The aircraft is flying northeast and looking left. The elevation angle between the ground points and airborne platform ranges from about $27^{\circ}-65^{\circ}$. Top right: A profile line of sight ground range change across the fault is plotted and slip across the fault is estimated. Lower right: Two profiles on either side of the fault are differenced. The profiles are $1.25 \mathrm{~km}$ apart. Data and profiles were viewed and extracted from GeoGateway [69]. Principal investigator for this flight line is Paul Lundgren, JPL [84]. Red arrow points to location of image in Figure 8.

\subsection{Carrizo Section San Andreas Fault-A Mature and Locked Fault}

The Carrizo Plain area, situated in the southeastern California Coast Ranges (Figures 1 and 10), contains the premier geomorphic example of the San Andreas fault system in California. The SAF in the Carrizo Plain has the largest accumulated post-early Miocene offset and is the oldest reach of the entire active fault system (315 km and $15 \mathrm{Ma}$; [85]). The area has long been regarded as a site of world-class examples of strike-slip faulting (e.g., [86-91]). The SAF follows the northeastern side of the plain and along it are offset, beheaded, and abandoned drainages that reflect recent strike-slip motion. That motion has been accommodated by great earthquakes; the most recent was the 1857 Fort Tejón earthquake [92-94]. Earlier offsets and paleoruptures are evident as well $[88,93,95]$. The geodetic measure of strain accumulation [96] is within error of the millennial scale fault slip rate of $\sim 34 \mathrm{~mm} /$ year $[88,97,98]$. The record of faulting is of fundamental importance for testing models of earthquake physics and for constraining the significant earthquake hazard faced by southern California [1]. 


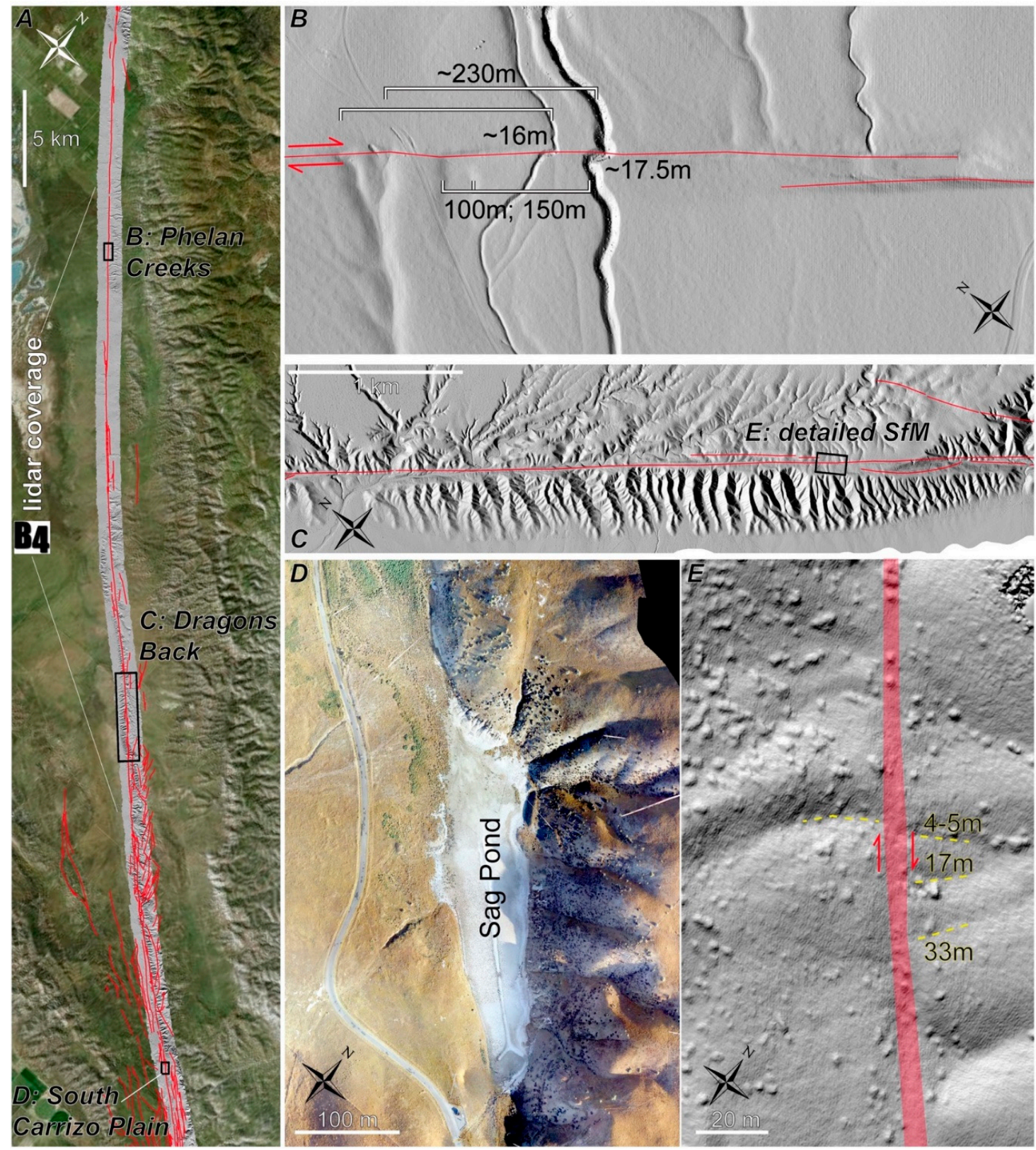

Figure 10. Lidar and Structure from Motion (SfM) for the Carrizo Plain: (A) B4 lidar [99] coverage strip along the San Andreas fault in the Carrizo Plain with US Geological Survey Quaternary Faults [100] (red); (B) B4 hillshade (0.5 m/pixel) depicts spectacular tectonic landforms at Phelan Creeks where millennial scale offsets are consistent with $\sim 33 \mathrm{~mm} /$ year slip rate [98,101]; (C) lidar topography provides the basis for detailed geomorphic analysis of the Dragon's Back pressure ridge [90]; (D) SfM-derived orthophoto (6 cm/pixel) shows sag pond along the San Andreas fault in southern Carrizo Plain [91]; and (E) SfM-derived hillshade (0.2 m/pixel) provides basis for fine scale offset landform reconstruction (e.g., [98,102]).

Lidar topography and SfM have been transformative for active faulting studies along the SAF in the Carrizo Plain. Figure 10 illustrates a series of many possible examples. The SAF was laser scanned as part of the B4 project [99]. The data are invaluable for mapping the fault traces, reconstructing offsets, and inferring geomorphic response to rock uplift. Detailed mapping of the SAF trace is enabled with the fine resolution and high spatial accuracy of the lidar topography (e.g., [103]). The extent of lidar coverage from the 2005 B4 Lidar Project survey is 1-2 km wide with typical shot densities of 4 points/sq. 
meter (Figure 10A). Millennial-scale offsets preserved at Phelan Creeks (Figure 10B) are consistent with $34 \mathrm{~mm} /$ year slip rates [98]. Reconstruction of the offsets and the complex, possibly climate-modulated incision, aggradation, abandonment, and offset sequences [101] are significantly aided with the high quality lidar topography. The Dragon's Back pressure ridge (Figure 10C) shows progressive landscape development associated with rock uplift and translation relative to a fixed "knuckle" along the SAF at a few hundred $m$ depth [90]. The progression can be used in a substitution of space-for-time to explore surface process response to transient rock uplift and to assess the value of computed topographic metrics. Along with the high-resolution topography, the $\mathrm{SfM}$ provides $\mathrm{cm} /$ pixel resolution orthophotography, which acts as a valuable basis for site description for example at the South Carrizo sag pond site [91]. The sags are local depressions along the fault zone, developed from both structural depression and topographic juxtaposition. Finally, while the uniform quality (typically gridded at 0.5 to $1 \mathrm{~m} /$ pixel) and great extent of the B4 made it the main data source for offset reconstruction studies (see review [102]), the SfM provides even higher resolution topography ( 0.1 m/pixel) for paleoseismic site investigations and more detailed offset reconstructions (e.g., [98]). Figure 10E shows an example of the SAF trace along the Dragon's Back where meter- to dekameter-scale offsets can be reconstructed. Most of the slip is confined to the fault trace and not distributed more broadly.

\subsection{Landers Rupture: Geomorphic Modifications to Earthquake Surface Rupture}

The Eastern California Shear Zone lies directly north and northeast of the southern Bend of the SAF. The 28 June 1992 Landers, California, earthquake (Mw 7.3) ruptured a northwest trending zone in the Mojave Desert [12] within the Eastern California Shear Zone. It formed a remarkable scarp along the Emerson Fault which has been repeatedly surveyed, allowing the original form of and modifications to the earthquake surface rupture to be described $[20,104,105]$. The rupture cut across a low relief and low gradient west-draining watershed along which there was limited evidence of pre-1992 faulting. The rupture was discontinuous with overlapping traces. At the Emerson Fault site, horizontal offsets were as much as $4 \mathrm{~m}$, and 1-2 $\mathrm{m}$ high west-facing scarps formed.

Field observations and detailed topographic surveys document the modifications of the scarps and knickpoints. Early surveys were made with a total station with only hundreds of points to sample the ground [104]. In 2008, the site was scanned using a terrestrial laser scanner, producing more than 8 million ground points $[105,106]$. In 2012, a balloon-based system was used to fly a Nikon DSLR along the rupture and produced a high-quality SfM dataset of $\sim 100$ million points and a $2 \mathrm{~cm}$ digital elevation model [20,107] (Figure 11). Finally, in 2016, a sUAS was used to image a broad swath of the site with similar point densities as in 2012 (Figure 11).

Geomorphic modifications to the sharp surface rupture are notable. Some of the scarps are still steep and show modest smoothing from raindrop impact and eolian abrasion with small colluvial wedges at their bases. The most dramatic geomorphic response has been the incision by narrow channels as knickpoints cut headward across the faulted valleys. The initial forms of the valleys were broad with just a few decimeters of relief. After nearly 25 years, the meter-high knickpoints have been intricately incised. The incision signal has moved more than $20 \mathrm{~m}$ upstream in some of the valleys (Figure 11). Incision and headward propagation rate appear to depend on drainage basin hypsometry and substrate permeability. Assuming the pre-1992 rupture (approximately $10 \mathrm{ka}$; [108]) had a similar vertical component, consistent with the few degraded scarps observed, this style of narrow knickpoint incision must propagate headward and then channels widen and valley floor relief decreases attesting to the long time between events.

These topographic datasets provide invaluable information about the style, rates, and controls on landscape response to sharp perturbations such as surface rupture. A remaining challenge for their analysis will be alignment, scaling, and georeferencing of the successively acquired topographic datasets. 


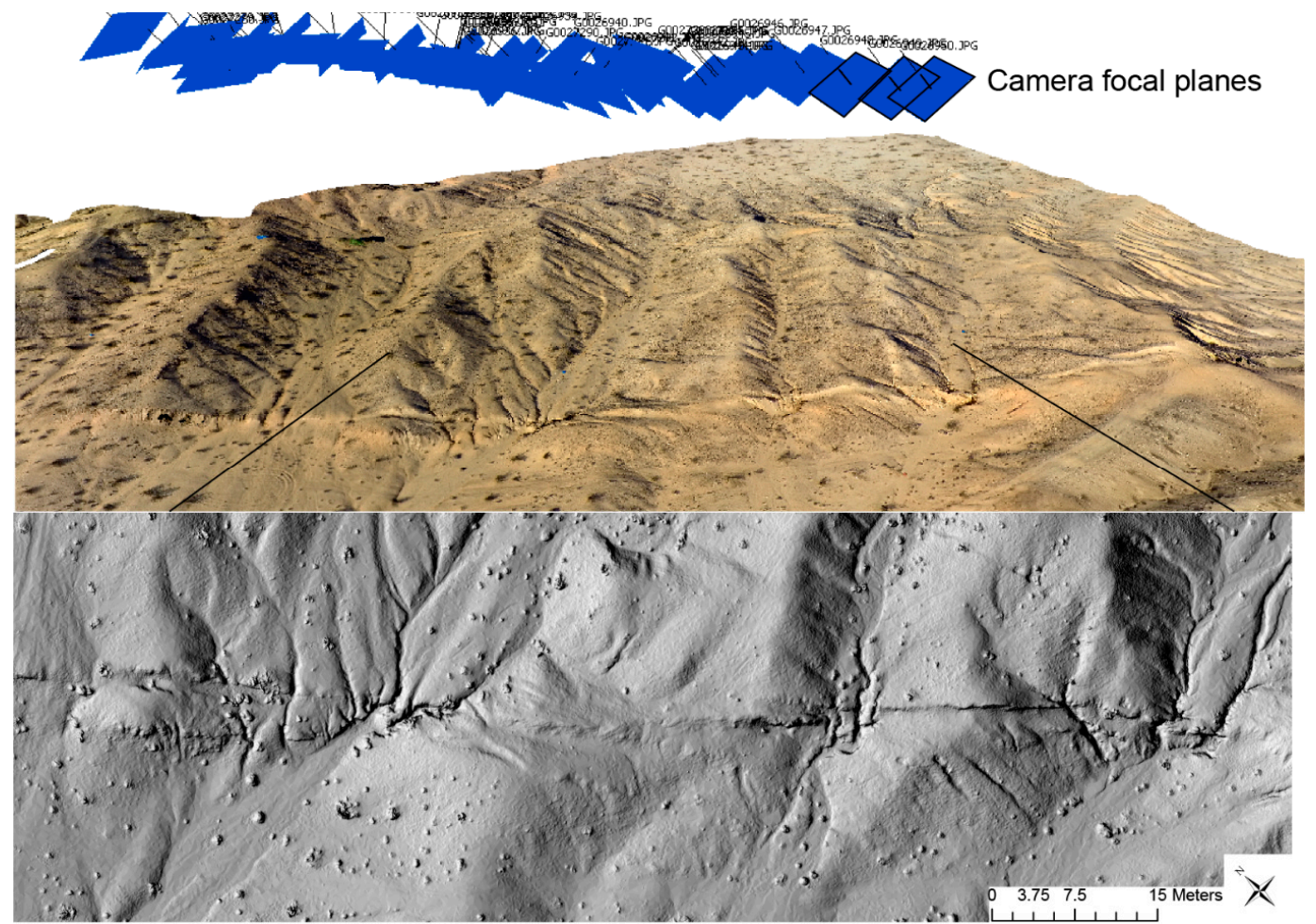

Figure 11. Structure from motion documentation of the degrading surface rupture of the 1992 Landers earthquake along the Emerson Fault in the Mojave Desert, California. The upper oblique image (view to the east northeast) is a portion of the model computed from the 2016 small unmanned aerial system survey (blue squares indicate focal plane positions and orientations for the photographs). The discontinuous and bending fault trace is evident. The image also provides context for the lower map. The 2012 data [20] are presented as a $2 \mathrm{~cm}$ per pixel hillshade map along which the overlapping traces at the left are evident. The incising valleys show sharp knick channels across the otherwise relatively smooth topography.

\subsection{The Convergence of the San Andreas and Eastern California Shear Zones}

The SAF and southern extension of the Landers rupture and Eastern California Shear zone meet at the Coachella segment of the SAF. It is also possible that SAF ruptures can jump to the San Jacinto fault a the Cajon Pass [109] consistent with geodetic evidence (Figure 4). The Eastern California Shear Zone extends into the southernmost SAF at the Coachella Segment [110]. The San Jacinto fault is more favorably oriented with the SAF to the north and the Coachella segment of the SAF and Eastern California Shear Zone are also favorably oriented. The deformation and extension of the San Jacinto and Coachella Segments of the SAF meet in the Imperial Valley appearing to form a single fault zone that extends into the Gulf of California.

The 2010 M7.2 El Mayor-Cucapah earthquake triggered slip on numerous faults north and northeast of the rupture between the Mexican border and the SAF [38,111,112]. These networks of faults connect the El Mayor-Cucapah rupture with the Elsinore, San Jacinto, and SAF. Postseismic deformation is greatest in the Salton Trough. Postseismic fault slip of $\sim 10-40 \mathrm{~cm}$ was located mainly on the periphery of the main coseismic fault patches and additional deformation occurred further north [113]. A seismic swarm occurred in the Salton Trough in 2012 [114-116] and another one occurred further north in 2016. These are consistent with the postseismic deformation and suggest a connection to the Southern San Andreas Eastern California Shear Zone and a compliant crust. Long-term creep on the Coachella Segment [117] and triggered slip on the same segment following the Landers and El Mayor-Cucapah events also suggests that the fault is weak $[118,119]$. Additionally the Eureka Peak fault actively creeps following large earthquakes $[7,120]$. The San Jacinto fault shows no evidence of 
triggered slip or creep based on examination of seven years of UAVSAR observations implying that the fault is locked, stronger, and may produce larger earthquakes $[1,38]$.

\section{Measurement Requirements and Discussion}

Across spatial scales, compliant zones of deformation are bounded by more rigid blocks. Distributed deformation occurs across the plate boundary, but narrow zones of shear extend from the Gulf of California and split to follow the San Andreas fault and the Eastern California Shear Zone. Distributed inelastic deformation is also associated with earthquakes and in most of the examples shallow slip is triggered along faults far from the main rupture. The interactions between surface process and deformation produce interpretable tectonic geomorphology and the resulting landscapes can be interrogated to establish time scales of events and relative process rates.

In this paper, we show observational evidence of localized and broad scale deformation ranging from meters to hundreds of kilometers. Understanding the full range of scales and separating plastic from elastic deformation is required to properly model lithospheric structure and assess potential rupture characteristics. The relative compliance of faults and lithospheric structures control the location of and fragmentation of the Pacific-North American plate boundary and rupture characteristics. The questions outlined in this paper can be addressed by a suite of targeted measurements and modeling of fault processes within the lithospheric structure (Table 1).

Table 1. Science objectives with needed measurements and resolution requirements.

\begin{tabular}{|c|c|c|c|}
\hline Objective & Measurement & Technique & Resolution \\
\hline \multirow{9}{*}{$\begin{array}{l}\text { Measure distribution of } \\
\text { deformation across the } \\
\text { plate boundary }\end{array}$} & \multirow{9}{*}{$\begin{array}{l}\text { Crustal } \\
\text { Deformation }\end{array}$} & \multirow{3}{*}{ GPS } & $10 \mathrm{~km}$ spacing \\
\hline & & & $500 \mathrm{~km} \times 1500 \mathrm{~km}$ field of view \\
\hline & & & $1 \mathrm{~mm} /$ year \\
\hline & & \multirow{3}{*}{ UAVSAR } & 10 m pixel spacing \\
\hline & & & $10 \mathrm{~km} \times 10 \mathrm{~km}$ field of view \\
\hline & & & $1 \mathrm{~cm} /$ year \\
\hline & & \multirow{3}{*}{ Airborne lidar } & $1 \mathrm{~m}$ spacing \\
\hline & & & $10 \mathrm{~km} \times 10 \mathrm{~km}$ field of view \\
\hline & & & $1 \mathrm{~cm} /$ year \\
\hline \multirow{10}{*}{$\begin{array}{l}\text { Determine interactions } \\
\text { between faults within } \\
\text { the plate boundary }\end{array}$} & \multirow{10}{*}{ Fault Traces } & \multirow{3}{*}{ GPS } & $10 \mathrm{~km}$ spacing \\
\hline & & & $50 \mathrm{~km} \times 50 \mathrm{~km}$ field of view \\
\hline & & & $1 \mathrm{~cm} /$ day time dependent rates \\
\hline & & \multirow{3}{*}{ UAVSAR } & $\leq 10 \mathrm{~m}$ posting \\
\hline & & & $5 \mathrm{~km} \times 5 \mathrm{~km}$ field of view \\
\hline & & & $1 \mathrm{~cm}$ \\
\hline & & \multirow{2}{*}{ Airborne lidar } & $2 \mathrm{~km} \times 2 \mathrm{~km}$ field of view \\
\hline & & & $\leq 1 \mathrm{~m}$ \\
\hline & & \multirow{2}{*}{$\begin{array}{l}\text { Structure from motion }(\mathrm{SfM}) \\
\text { from ground or near surface }\end{array}$} & $1 \mathrm{~m}$ posting \\
\hline & & & $2 \mathrm{~km} \times 2 \mathrm{~km}$ field of view \\
\hline \multirow{7}{*}{$\begin{array}{l}\text { Assess what fraction of } \\
\text { strain accumulation is } \\
\text { released aseismically }\end{array}$} & \multirow{7}{*}{$\begin{array}{l}\text { Fault zone } \\
\text { landforms }\end{array}$} & \multirow{3}{*}{ UAVSAR } & $\leq 10 \mathrm{~m}$ posting \\
\hline & & & $5 \mathrm{~km} \times 5 \mathrm{~km}$ field of view \\
\hline & & & $1 \mathrm{~cm}$ \\
\hline & & \multirow{2}{*}{ Ground and airborne lidar } & $2 \mathrm{~km} \times 2 \mathrm{~km}$ field of view \\
\hline & & & $\leq 1 \mathrm{~m}$ \\
\hline & & \multirow{2}{*}{$\begin{array}{l}\text { Structure from motion (SfM) } \\
\text { from ground or near surface }\end{array}$} & $1 \mathrm{~m}$ posting \\
\hline & & & $2 \mathrm{~km} \times 2 \mathrm{~km}$ field of view \\
\hline
\end{tabular}




\subsection{Connecting Plate Boundary Motions to Surface Faults and Their Associated Deformation}

Understanding how faults interact across the plate boundary requires measurement of crustal deformation at the level of individual faults. GPS measurements elucidate the total plate rate as well as block motions and zones of rapid deformation. The approximately $10 \mathrm{~km}$ station spacing in California at $1 \mathrm{~mm} /$ year rates is useful for focusing attention on areas of rapid deformation and for determining slip partitioning between faults. The high temporal sampling of GPS is particularly important for measuring and modeling postseismic deformation and processes.

The $10 \mathrm{~km}$ scale of GPS velocity measurements does not provide details about how slip is distributed across individual fault zones, nor does it provide detail of slip variations along strike. UAVSAR measurements fill in that gap in measurement. The $7 \mathrm{~m}$ pixel spacing of UAVSAR provides details of slip near fault zones. In the near-field UAVSAR accuracy is on the order of $1 \mathrm{~cm}$. Over a few $\mathrm{km}$, due to error introduced by tropospheric water vapor the accuracy can degrade to up to $3 \mathrm{~cm}$. These measurements are important for detecting shallow slip that does not influence the farther field. When combined with GPS measurements, a much better assessment can be made of how deeply shallow slip extends and the extent of off fault deformation. Though UAVSAR measurements are not as accurate as GPS they have proven useful for identifying localized slip across faults [38-40], including faults triggered by distant earthquakes [72,112]. In general, significant triggered slip is several $\mathrm{cm}$, outside the error of the UAVSAR measurements. UAVSAR measurements can decorrelate in areas most disrupted by an earthquake, leaving a gap in areas that may be of substantial interest.

Topographic differencing provides a means of identifying surface ruptures when UAVSAR fails. Optical SfM topographic data have the additional value of allowing for image change detection or for simply providing imagery for studying surface disruption, and surface soil, rock, or vegetation characteristics. One-meter resolution is adequate for measuring offset features and local surface disruption. Topographic differencing applied to landslides (e.g., [121]) and earthquake displacements (e.g., [59]) requires sufficiently dense sampling to measure submeter offsets. In addition, temporal repeat and response must be sufficient to capture events of interest which can be sub-daily for immediate postseismic deformation and yearly for long-term deformation.

\subsection{Fault Rupture and Slip throughout Multiple Earthquake Cycles}

Building a history of fault rupture and slip characteristics throughout multiple earthquake cycles is necessary for determining how faults interact within the plate boundary. Seismology provides an excellent means of understanding fault ruptures. Computer simulations (e.g., [122]) provide a means of building up long catalogs of possible earthquake histories to interrogate for statistical relations between earthquakes and fault network geometry. Paleoseismology provides information about fault rupture, slip, and timing of events at points along fault segments. Measurements that encompass entire fault traces show rupture characteristics, fault zone complexity from geomorphic features such as branches or jumps, and time-dependent slip properties.

InSAR and topographic differencing along fault ruptures allows for unprecedented observation of surface rupture characteristics and triggered slip on other faults. Rapid response following an event and then repeated measurements following the event yield time-dependent deformation from which models of postseismic processes can be constructed. Airborne UAVSAR provides higher resolution than spaceborne InSAR with configurable flight paths. Spaceborne InSAR has the advantage of producing systematic repeated measurements. When fused with GPS position time series, a high resolution spatio-temporal observation of crustal deformation can be constructed. GPS measurements provide time-dependent characterization of faults and the crustal deformation following earthquakes and provide potential for detecting transient slip behavior or the propagation of deformation associated with earthquakes along fault traces.

Topographic models draped with color imagery can be used to elucidate details about fault traces and past ruptures. Identification of meter-scale features requires high accuracy georeferenced images for mapping. From these measurements offset landforms can be reconstructed. Decimeter 
scale sampling is required to identify and interpret post-offset modifications for meter to dekameter scale offsets as well as for landscape elements sensitive to repeated earthquake displacements. Critical breaks in landscape length scale depend on surface process types and rates, degree of soil mantle and rock outcrop, etc. While hillslope lengths and drainage density may be sufficiently resolved at dekameter length scales (see review [123]), some sensitive elements are much finer (e.g., places like Carrizo Plain). These include hilltop curvature (e.g., [124]), channel head locations and shallow landslide behavior ([90] for example).

\subsection{Implications for Earthquake Hazard}

Geodetic imaging contributes to assessment of earthquake hazard, providing estimates of rupture potential and fault interactions. Determining the partitioning of seismic and aseismic motion enables a more accurate assessment of potential moment release from earthquakes. Evidence is accumulating that a non-trivial component of strain accumulation is relieved aseismically. The measurements discussed here can provide an accounting of these aseismic contributions to the plate boundary motion. Fault afterslip is pervasive in California following large earthquakes (e.g., [120,125,126]) and can contribute substantial slip to a fault rupture. GPS measurements and rapid repeated measurement from UAVSAR and topographic differencing can aid in measurement and assessment of afterslip. Decimeter level estimate of afterslip for large earthquakes would improve estimates of the fraction of aseismic versus seismic slip on faults.

Aseismic deformation can also occur as triggered slip on other faults, discussed earlier, or can be plastically distributed across a fault zone. Such fault zone distributed deformation is suggested along the SAF for the 1857 Fort Tejon earthquake [127] and possibly for the creeping section of the SAF. Spatial sampling of $1 \mathrm{~m}$ or finer across fault zones will clarify the significance of off-fault plastic deformation of the crust.

\section{Conclusions}

Multiscale measurements of spatio-temporal patterns of deformation and landforms within plate boundary systems (Figure 12) are necessary for improved understanding of earthquakes and tectonic deformation. Accurate assessment of rupture characteristics and seismic moment release through seismic cycles requires an accounting of deformation ranging from meter-scale fault zones to $100-\mathrm{km}$-scale plate boundaries. Several geodetic imaging techniques fill in different temporal and spatial scales of lithospheric processes: GPS, InSAR, lidar, and Structure from Motion. In California, the South Napa earthquake slipped several kilometers from the main mapped fault trace and produced substantial afterslip on the main rupture. The creeping section of the San Andreas fault, while weak, may exhibit more distributed off-fault deformation than the stronger Carrizo segment of the fault. Farther south, the Coachella segment of the San Andreas fault may be weak and connect the Eastern California Shear Zone and the Gulf of California, while the stronger San Jacinto fault connects the Gulf of California with the San Andreas fault further north.

At the finest scale, fault creep, coseismic and postseismic deformation, as well as triggered slip of nearby structures can be measured using topographic and UAVSAR data, as exemplified by work done following the south Napa earthquake, the El Mayor-Cucapah earthquake, and along the creeping San Andreas fault. Landforms and deformation patterns at coarser scale, such as those preserved along the Carrizo Plain San Andreas fault and the San Jacinto fault can indicate fault behavior over longer timescales. Fine scale landscape changes following earthquakes can be detected using topographic measurements from laser scanners or optical sensors. Determining fault slip rates at the $\mathrm{mm} /$ year level from GPS can enable determination of partitioning between faults. Measurements across and within fault zones will clarify how fault ruptures have occurred previously, may propagate in the future, and illuminate what fraction of total strain accumulation is released aseismically. 


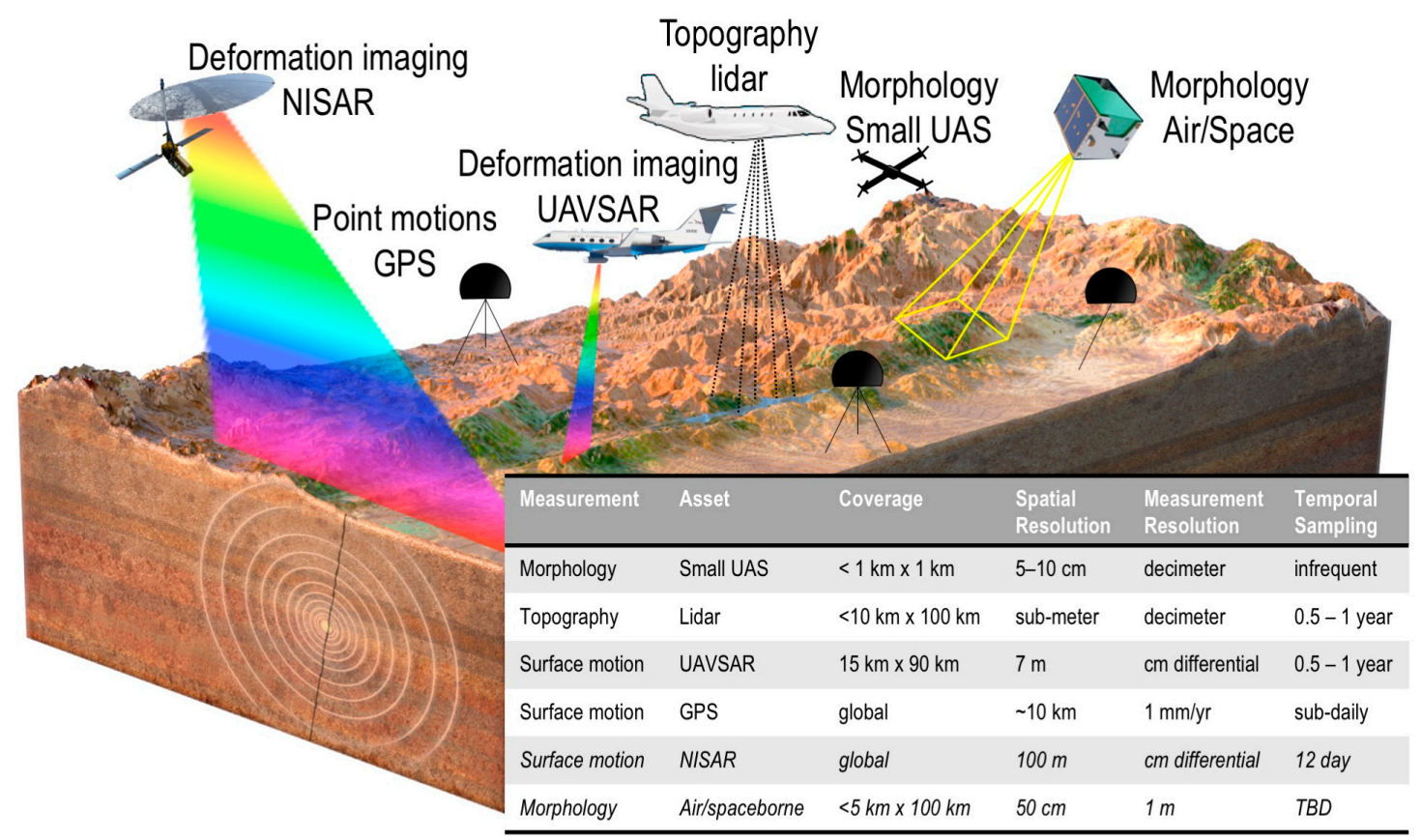

Figure 12. Measurements and assets applied to understanding plate boundary and fault processes with approximate coverage and resolution. The last two measurements are planned or notional and are italicized. Base art created by Chuck Carter. Figure modified from [128].

Acknowledgments: Portions of this work were carried out at the Jet Propulsion Laboratory, California Institute of Technology under contract with NASA. Sinan Akciz assisted in the imagery collection for the sag pond in Figure 9. Jessica Sutton assisted with SfM computations for Figures 9 and 10. Alexandra Pickering helped with terrestrial lidar data acquisition and processing for South Napa and the creeping SAF. The airborne lidar from the South Napa Earthquake was funded by the California Department of Water Resources, the US Geological Survey, the California Geological Survey, and PEER-GEER, coordinated by Kenneth Hudnut. Discussions with C. Crosby were helpful for the topography sections. DeLong was funded by the National Earthquake Hazards Reduction Program of the U.S. Geological Survey. Any use of trade, firm, or product names is for descriptive purposes only and does not imply endorsement by the U.S. Government.

Author Contributions: The authors of this paper contributed evenly throughout the paper. A. Donnellan led discussion of UAVSAR and GPS measurements. R. Arrowsmith and S. DeLong focused on the topographic and geomorphic discussion. R. Arrowsmith focused on the Carrizo Plain and Landers regions. S. DeLong focused on the South Napa and Creeping sections of the SAF. A. Donnellan focused on the broader picture of crustal deformation.

Conflicts of Interest: The authors declare no conflict of interest.

\section{References}

1. Field, E.H.; Arrowsmith, R.J.; Biasi, G.P.; Bird, P.; Dawson, T.E.; Felzer, K.R.; Jackson, D.D.; Johnson, K.M.; Jordan, T.H.; Madden, C. Uniform California Earthquake Rupture Forecast, version 3 (UCERF3)-The time-independent model. Bull. Seismol. Soc. Am. 2014, 104, 1122-1180. [CrossRef]

2. Rundle, J.B.; Turcotte, D.L.; Shcherbakov, R.; Klein, W.; Sammis, C. Statistical physics approach to understanding the multiscale dynamics of earthquake fault systems. Rev. Geophys. 2003, 41. [CrossRef]

3. Council, N.R. Landscapes on the Edge: New Horizons for Research on Earth's Surface; National Academies Press: Washington, DC, USA, 2010.

4. Sauber, J.; Thatcher, W.; Solomon, S.C.; Lisowski, M. Geodetic slip rate for the eastern California shear zone and the recurrence time of Mojave Desert earthquakes. Nature 1994, 367, 264-266. [CrossRef]

5. Wesnousky, S.G. The San Andreas and Walker Lane fault systems, western North America: Transpression, transtension, cumulative slip and the structural evolution of a major transform plate boundary. J. Struct. Geol. 2005, 27, 1505-1512. [CrossRef] 
6. Meade, B.J.; Hager, B.H. Block models of crustal motion in southern California constrained by GPS measurements. J. Geophys. Res. Solid Earth 2005, 110, 1-19. [CrossRef]

7. Spinler, J.C.; Bennett, R.A.; Anderson, M.L.; McGill, S.F.; Hreinsdóttir, S.; McCallister, A. Present-day strain accumulation and slip rates associated with southern San Andreas and eastern California shear zone faults. J. Geophys. Res. Solid Earth 2010, 115, B11407. [CrossRef]

8. Rockwell, T.; Loughman, C.; Merifield, P. Late Quaternary rate of slip along the San Jacinto fault zone near Anza, southern California. J. Geophys. Res. Solid Earth 1990, 95, 8593-8605. [CrossRef]

9. Fletcher, K.E.; Rockwell, T.K.; Sharp, W.D. Late Quaternary slip rate of the southern Elsinore fault, Southern California: Dating offset alluvial fans via 230Th/U on pedogenic carbonate. J. Geophys. Res. Earth Surf. 2011, 116. [CrossRef]

10. Stein, R.S.; Barka, A.A.; Dieterich, J.H. Progressive failure on the North Anatolian fault since 1939 by earthquake stress triggering. Geophys. J. Int. 1997, 128, 594-604. [CrossRef]

11. Barka, A.; Akyüz, H.S.; Altunel, E.; Sunal, G.; Cakir, Z.; Dikbas, A.; Yerli, B.; Armijo, R.; Meyer, B.; De Chabalier, J.B. The surface rupture and slip distribution of the 17 August 1999 Izmit earthquake (M 7.4), North Anatolian fault. Bull. Seismol. Soc. Am. 2002, 92, 43-60. [CrossRef]

12. Sieh, K.; Jones, L.; Hauksson, E.; Hudnut, K.; Eberhart-Phillips, D.; Heaton, T.; Hough, S.; Hutton, K.; Kanamori, H.; Lilje, A. Near-field investigations of the Landers earthquake sequence, April to July 1992. Science 1993, 260, 171-176. [CrossRef] [PubMed]

13. Heflin, M.; Dong, D.; Donnellan, A.; Hurst, K.; Jefferson, D.; Watkins, M.; Webb, F.; Zumberge, J.; Dauger, D.; Lyzenga, G. Rate change observed at JPLM after the Northridge earthquake. Geophys. Res. Lett. 1998, 25, 93-96. [CrossRef]

14. Wells, D.L.; Coppersmith, K.J. New empirical relationships among magnitude, rupture length, rupture width, rupture area, and surface displacement. Bull. Seismol. Soc. Am. 1994, 84, 974-1002.

15. Aki, K. Characterization of barriers on an earthquake fault. J. Geophys. Res. Solid Earth 1979, 84, 6140-6148. [CrossRef]

16. Harris, R.A.; Day, S.M. Dynamics of fault interaction: Parallel strike-slip faults. J. Geophys. Res. Solid Earth 1993, 98, 4461-4472. [CrossRef]

17. Harding, T.P. Seismic characteristics and identification of negative flower structures, positive flower structures, and positive structural inversion. AAPG Bull. 1985, 69, 582-600.

18. Cowie, P. A.; Scholz, C. H. Physical explanation for the displacement-length relationship of faults using a post-yield fracture mechanics model. J. Struct. Geol. 1992, 14, 1133-1148. [CrossRef]

19. Cochran, E. S.; Li, Y.-G.; Shearer, P. M.; Barbot, S.; Fialko, Y.; Vidale, J. E. Seismic and geodetic evidence for extensive, long-lived fault damage zones. Geology 2009, 37, 315-318. [CrossRef]

20. Johnson, K.; Nissen, E.; Saripalli, S.; Arrowsmith, J.R.; McGarey, P.; Scharer, K.; Williams, P.; Blisniuk, K. Rapid mapping of ultrafine fault zone topography with structure from motion. Geosphere 2014, 10, 969-986. [CrossRef]

21. Hudnut, K.W.; Bock, Y.; Galetzka, J.E.; Webb, F.H.; Young, W.H. The southern California integrated GPS network (SCIGN). In Proceedings of the 10th FIG International Symposium on Deformation Measurements, Orange, CA, USA, 19-22 March 2001; pp. 19-22.

22. Donnellan, A.; Hager, B.H.; King, R.W.; Herring, T.A. Geodetic measurement of deformation in the Ventura Basin region, Southern California. J. Geophys. Res. Solid Earth 1993, 98, 21727-21739.

23. Feigl, K.L.; Agnew, D.C.; Bock, Y.; Dong, D.; Donnellan, A.; Hager, B.H.; Herring, T.A.; Jackson, D.D.; Jordan, T.H.; King, R.W. Space geodetic measurement of crustal deformation in central and southern California, 1984-1992. J. Geophys. Res. Solid Earth 1993, 98, 21677-21712. [CrossRef]

24. Donnellan, A.; Hager, B.H.; King, R.W. Discrepancy between geological and geodetic deformation rates in the Ventura Basin. Nature 1993, 366, 333-336. [CrossRef]

25. Hudnut, K.W.; Shen, Z.; Murray, M.; McClusky, S.; King, R.; Herring, T.; Hager, B.; Feng, Y.; Fang, P.; Donnellan, A. Co-seismic displacements of the 1994 Northridge, California, earthquake. Bull. Seismol. Soc. Am. 1996, 86, S19-S36.

26. Silver, P.G.; Bock, Y.; Agnew, D.C.; Henyey, T.; Linde, A.T.; McEvilly, T.V.; Minster, J.-B.; Romanowicz, B.A.; Sachs, I.S.; Smith, R.B.; et al. A plate boundary observatory. IRIS Newsl. 1999, 16, 3. Available online: http:/ / ftp.iris.edu/news/IRISnewsletter/EE.Fall98.web/plate.html (accessed on 14 March 2017). 
27. Herring, T.A.; Melbourne, T.I.; Murray, M.H.; Floyd, M.A.; Szeliga, W.M.; King, R.W.; Phillips, D.A.; Puskas, C.M.; Santillan, M.; Wang, L. Plate Boundary Observatory and Related Networks: GPS Data Analysis Methods and Geodetic Products. Rev. Geophys. 2016, 54, 759-808. [CrossRef]

28. Argus, D.F.; Heflin, M.B. Plate motion and crustal deformation estimated with geodetic data from the Global Positioning System. Geophys. Res. Lett. 1995, 22, 1973-1976. [CrossRef]

29. Argus, D.F.; Fu, Y.; Landerer, F.W. Seasonal variation in total water storage in California inferred from GPS observations of vertical land motion. Geophys. Res. Lett. 2014, 41, 1971-1980.

30. Smith-Konter, B.R.; Sandwell, D.T.; Shearer, P. Locking depths estimated from geodesy and seismology along the San Andreas Fault System: Implications for seismic moment release. J. Geophys. Res. Solid Earth 2011, 116. [CrossRef]

31. Bürgmann, R.; Rosen, P.A.; Fielding, E.J. Synthetic aperture radar interferometry to measure Earth's surface topography and its deformation. Annu. Rev. Earth Planet. Sci. 2000, 28, 169-209.

32. Jones, C.E. A practical guide to synthetic aperture radar for engineering and environmental geologists. In Applied Geology in California, Special Publication 26; Anderson, R.L., Ferriz, H., Eds.; Association of Environmental and Engineering Geologists, Star Publishing Company: Redwood City, CA, USA, 2016.

33. Massonnet, D.; Rossi, M.; Carmona, C.; Adragna, F.; Peltzer, G.; Feigl, K.; Rabaute, T. The displacement field of the Landers earthquake mapped by radar interferometry. Nature 1993, 364, 138-142. [CrossRef]

34. Rosen, P.A.; Kim, Y.; Hensley, S.; Shaffer, S.; Veilleux, L.; Hoffman, J.; Chuang, C.-L.; Chakraborty, M.; Sagi, V.R.; Satish, R. An L-and S-band SAR mission concept for Earth science and applications. In Proceedings of the EUSAR 2014 10th European Conference on Synthetic Aperture Radar, Berlin, Germany, 3-5 June 2014; pp. 1-4.

35. Hensley, S.; Wheeler, K.; Sadowy, G.; Jones, C.; Shaffer, S.; Zebker, H.; Miller, T.; Heavey, B.; Chuang, E.; Chao, R. The UAVSAR instrument: Description and first results. In Proceedings of the 2008 IEEE Radar Conference, Rome, Italy, 26-30 May 2008; pp. 1-6.

36. Hensley, S.; Zebker, H.; Jones, C.; Michel, T.; Muellerschoen, R.; Chapman, B. First deformation results using the NASA/JPL UAVSAR instrument. In Proceedings of the APSAR 2009 2nd Asian-Pacific Conference on Synthetic Aperture Radar, Xian, China, 26-30 October 2009; pp. 1051-1055.

37. Rosen, P.A.; Hensley, S.; Wheeler, K.; Sadowy, G.; Miller, T.; Shaffer, S.; Muellerschoen, R.; Jones, C.; Zebker, H.; Madsen, S. UAVSAR: A new NASA airborne SAR system for science and technology research. In Proceedings of the 2006 IEEE Conference on Radar, Verona, NY, USA, 24-27 April 2006; p. 8.

38. Donnellan, A.; Parker, J.; Hensley, S.; Pierce, M.; Wang, J.; Rundle, J. UAVSAR observations of triggered slip on the Imperial, Superstition Hills, and East Elmore Ranch Faults associated with the 2010 M 7.2 El Mayor-Cucapah earthquake. Geochem. Geophys. Geosyst. 2014, 15, 815-829. [CrossRef]

39. Donnellan, A.; Grant Ludwig, L.; Parker, J.W.; Rundle, J.B.; Wang, J.; Pierce, M.; Blewitt, G.; Hensley, S. Potential for a large earthquake near Los Angeles inferred from the 2014 La Habra earthquake. Earth Space Sci. 2015, 2, 378-385. [CrossRef] [PubMed]

40. DeLong, S.B.; Donnellan, A.; Ponti, D.J.; Rubin, R.S.; Lienkaemper, J.J.; Prentice, C.S.; Dawson, T.E.; Seitz, G.; Schwartz, D.P.; Hudnut, K.W. Tearing the terroir: Details and implications of surface rupture and deformation from the 24 August 2014 M6. 0 South Napa earthquake, California. Earth Space Sci. 2016, 3, 416-430. [CrossRef]

41. Willett, S.D.; Brandon, M.T. On steady states in mountain belts. Geology 2002, 30, 175-178. [CrossRef]

42. Kirby, E.; Whipple, K.X. Expression of active tectonics in erosional landscapes. J. Struct. Geol. 2012, 44, 54-75. [CrossRef]

43. Gallen, S.F.; Wegmann, K.W.; Bohnenstiehl, D.R. Miocene rejuvenation of topographic relief in the southern Appalachians. GSA Today 2013, 23, 4-10.

44. Arrowsmith, J.R. High Resolution Topography and Active Faulting; Grutzner, C., Choi, J.H., Edwards, P., Kim, Y.S., Eds.; Geological Society of Korea and the Korean Institute of Geoscience and Mineral Resources: Busan, Korea, 2014; Volume 5.

45. Donnellan, A.; Arrowsmith, R.; Ben-Zion, Y.; Rundle, J.; Grant Ludwig, L.; Glasscoe, M.; Ansar, A.; Parker, J.; De Jong, E.; Lundgren, P.; et al. Connecting Plate Boundary Processes to Earthquake Faults Using Geodetic and Topographic Imaging. Available online: http:/ /surveygizmoresponseuploads.s3.amazonaws. com/fileuploads/15647/2604456/105-57af35cccc6e67b33cf5caed44ad11e6_DonnellanAndrea.pdf (accessed 17 March 2017). 
46. Milliner, C.W.; Dolan, J.F.; Hollingsworth, J.; Leprince, S.; Ayoub, F.; Sammis, C.G. Quantifying near-field and off-fault deformation patterns of the $1992 \mathrm{Mw} 7.3$ Landers earthquake. Geochem. Geophys. Geosyst. 2015, 16, 1577-1598. [CrossRef]

47. Farr, T.G.; Kobrick, M. Shuttle Radar Topography Mission produces a wealth of data. Eos Trans. Am. Geophys. Union 2000, 81, 583-585. [CrossRef]

48. Reuter, H.I.; Neison, A.; Strobl, P.; Mehl, W.; Jarvis, A. A first assessment of ASTER GDEM tiles for absolute accuracy, relative accuracy and terrain parameters. In Proceedings of the 2009 IEEE International Geoscience and Remote Sensing Symposium, Cape Town, South Africa, 12-17 July 2009; Volume 5, pp. V240-V243.

49. Tachikawa, T.; Hato, M.; Kaku, M.; Iwasaki, A. Characteristics of ASTER GDEM version 2. In Proceedings of the 2011 IEEE International Geoscience and Remote Sensing Symposium (IGARSS), Vancouver, BC, Canada, 24-29 July 2011; pp. 3657-3660.

50. Ryan, W.B.; Carbotte, S.M.; Coplan, J.O.; O’Hara, S.; Melkonian, A.; Arko, R.; Weissel, R.A.; Ferrini, V.; Goodwillie, A.; Nitsche, F. Global multi-resolution topography synthesis. Geochem. Geophys. Geosyst. 2009, 10. [CrossRef]

51. Krieger, G.; Moreira, A.; Fiedler, H.; Hajnsek, I.; Werner, M.; Younis, M.; Zink, M. TanDEM-X: A satellite formation for high-resolution SAR interferometry. IEEE Trans. Geosci. Remote Sens. 2007, 45, 3317-3341. [CrossRef]

52. Crosby, C.J.; Arrowsmith, R.; Nandigam, V.; Baru, C. Online Access and Processing of LiDAR Topography Data; Cambridge University Press: Cambridge, UK, 2011.

53. Passalacqua, P.; Belmont, P.; Staley, D.M.; Simley, J.D.; Arrowsmith, J.R.; Bode, C.A.; Crosby, C.; DeLong, S.B.; Glenn, N.F.; Kelly, S.A. Analyzing high resolution topography for advancing the understanding of mass and energy transfer through landscapes: A review. Earth Sci. Rev. 2015, 148, 174-193. [CrossRef]

54. Prentice, C.S.; Crosby, C.J.; Whitehill, C.S.; Arrowsmith, J.R.; Furlong, K.P.; Phillips, D.A. Illuminating Northern California's active faults. Eos Trans. Am. Geophys. Union 2009, 90, 55.

55. Prentice, C.S. Coastal Marine Terraces of Northern California: A Datum for Estimating Pleistocene Slip Rate across the Northern San Andreas Fault. In Proceedings of the 2008 Joint Meeting of the Geological Society of America, Soil Science Society of America, American Society of Agronomy, Crop Science Society of America, Gulf Coast Association of Geological Societies with the Gulf Coast Section of SEPM, Houston, TX, USA, 5-9 October 2008.

56. Snyder, G.I.; Sugarbaker, L.J.; Jason, A.L.; Maune, D.F. National Requirements for Enhanced Elevation Data; Open File Report; US Geological Survey: Reston, VA, USA, 2013; Volume 1237, p. 371.

57. Oskin, M.E.; Arrowsmith, J.R.; Corona, A.H.; Elliott, A.J.; Fletcher, J.M.; Fielding, E.J.; Gold, P.O.; Garcia, J.J.G.; Hudnut, K.W.; Liu-Zeng, J. Near-field deformation from the El Mayor-Cucapah earthquake revealed by differential LIDAR. Science 2012, 335, 702-705. [CrossRef] [PubMed]

58. Glennie, C.L.; Hinojosa-Corona, A.; Nissen, E.; Kusari, A.; Oskin, M.E.; Arrowsmith, J.R.; Borsa, A. Optimization of legacy lidar data sets for measuring near-field earthquake displacements. Geophys. Res. Lett. 2014, 41, 3494-3501. [CrossRef]

59. Nissen, E.; Maruyama, T.; Arrowsmith, J.R.; Elliott, J.R.; Krishnan, A.K.; Oskin, M.E.; Saripalli, S. Coseismic fault zone deformation revealed with differential LiDAR: Examples from Japanese Mw 7 intraplate earthquakes. Earth Planet. Sci. Lett. 2014, 405, 244-256. [CrossRef]

60. Duffy, B.; Quigley, M.; Barrell, D.J.; Van Dissen, R.; Stahl, T.; Leprince, S.; McInnes, C.; Bilderback, E. Fault kinematics and surface deformation across a releasing bend during the $2010 \mathrm{Mw} 7.1$ Darfield, New Zealand, earthquake revealed by differential LiDAR and cadastral surveying. Geol. Soc. Am. Bull. 2013, 125, 420-431.

61. Brooks, B.A.; Glennie, C.; Hudnut, K.W.; Ericksen, T.; Hauser, D. Mobile laser scanning applied to the earth sciences. Eos Trans. Am. Geophys. Union 2013, 94, 313-315. [CrossRef]

62. Kayen, R.; Pack, R.T.; Bay, J.; Sugimoto, S.; Tanaka, H. Terrestrial-LIDAR visualization of surface and structural deformations of the 2004 Niigata Ken Chuetsu, Japan, earthquake. Earthq. Spectra 2006, 22, 147-162.

63. Gold, P.O.; Oskin, M.E.; Elliott, A.J.; Hinojosa-Corona, A.; Taylor, M.H.; Kreylos, O.; Cowgill, E. Coseismic slip variation assessed from terrestrial LiDAR scans of the El Mayor-Cucapah surface rupture. Earth Planet. Sci. Lett. 2013, 366, 151-162.

64. Wilkinson, M.; McCaffrey, K.J.W.; Roberts, G.; Cowie, P.A.; Phillips, R.J.; Michetti, A.M.; Vittori, E.; Guerrieri, L.; Blumetti, A.M.; Bubeck, A. Partitioned postseismic deformation associated with the 2009 Mw 6.3 L'Aquila earthquake surface rupture measured using a terrestrial laser scanner. Geophys. Res. Lett. 2010, 37. [CrossRef] 
65. DeLong, S.B.; Lienkaemper, J.J.; Pickering, A.J.; Avdievitch, N.N. Rates and patterns of surface deformation from laser scanning following the South Napa earthquake, California. Geosphere 2015, 11. [CrossRef]

66. McClusky, S.C.; Bjornstad, S.C.; Hager, B.H.; King, R.W.; Meade, B.J.; Miller, M.M.; Monastero, F.C.; Souter, B.J. Present day kinematics of the eastern California shear zone from a geodetically constrained block model. Geophys. Res. Lett. 2001, 28, 3369-3372. [CrossRef]

67. Dixon, T.H.; Miller, M.; Farina, F.; Wang, H.; Johnson, D. Present-day motion of the Sierra Nevada block and some tectonic implications for the Basin and Range province, North American Cordillera. Tectonics 2000, 19, 1-24. [CrossRef]

68. Hearn, E.H.; Humphreys, E.D. Kinematics of the southern Walker Lane Belt and motion of the Sierra Nevada block, California. J. Geophys. Res. Solid Earth 1998, 103, 27033-27049.

69. GeoGateway Tools for Modeling, Analysis, and Response. Available online: http://geo-gateway.org (accessed on 17 March 2017).

70. Donnellan, A.; Parker, J.; Glasscoe, M.; Granat, R.; Pierce, M.; Wang, J.; Ma, Y.; Ludwig, L.G.; Rundle, J. GeoGateway: A system for analysis of UAVSAR data products. In Proceedings of the 2016 IEEE International Geoscience and Remote Sensing Symposium (IGARSS), Beijing, China, 10-15 July 2016; pp. 210-213.

71. Jet Propulsion Laboratory GPS Time Series. Available online: http://sideshow.jpl.nasa.gov/post/series.html (accessed on 17 March 2017).

72. Hudnut, K.W.; Brocher, T.M.; Prentice, C.S.; Boatwright, J.; Brooks, B.A.; Aagaard, B.T.; Blair, J.L.; Fletcher, J.B.; Erdem, J.E.; Wicks, C.W. Key Recovery Factors for the August 24, 2014, South Napa Earthquake; Open File Report; US Geological Survey: Reston, VA, USA, 2014; Volume 1249, p. 51.

73. Lydaa, A.W.; Zhanga, X.; Glenniea, C.L.; Hudnutb, K.; Brooksc, B.A. Airborne Light Detection and Ranging (LIDAR) Derived Deformation from the Mw 6.0 24 August, 2014 South Napa Earthquake Estimated by Two and Three Dimensional Point Cloud Change Detection Techniques. In Proceedings of the International Archives of the Photogrammetry, Remote Sensing and Spatial Information Sciences, Prague, Czech Republic, 12-19 July 2016; pp. 35-42.

74. DeLong, S.B. 3D Point Cloud Data from Laser Scanning along the 2014 South Napa Earthquake Surface Rupture, California, USA. Available online: https://www.sciencebase.gov/catalog/item/ 57f26aebe4b0bc0bebfff915 (accessed on 14 March 2017).

75. Graymer, R.W.; Brabb, E.E.; Jones, D.J.; Barnes, J.; Nicholson, R.S.; Stamski, R.E. Geologic Map and Map Database of Eastern Sonoma and Western Napa Counties, California; Geological Survey: Reston, VA, USA, 2007.

76. Jolivet, R.; Simons, M.; Agram, P.S.; Duputel, Z.; Shen, Z.-K. Aseismic slip and seismogenic coupling along the central San Andreas Fault. Geophys. Res. Lett. 2015, 42, 297-306.

77. Maurer, J.; Johnson, K. Fault coupling and potential for earthquakes on the creeping section of the central San Andreas Fault. J. Geophys. Res. Solid Earth 2014, 119, 4414-4428. [CrossRef]

78. Burford, R.O.; Harsh, P.W. Slip on the San Andreas fault in central California from alinement array surveys. Bull. Seismol. Soc. Am. 1980, 70, 1233-1261.

79. Lisowski, M.; Prescott, W.H. Short-range distance measurements along the San Andreas fault system in central California, 1975 to 1979. Bull. Seismol. Soc. Am. 1981, 71, 1607-1624.

80. Titus, S.J.; DeMets, C.; Tikoff, B. Thirty-five-year creep rates for the creeping segment of the San Andreas fault and the effects of the 2004 Parkfield earthquake: Constraints from alignment arrays, continuous global positioning system, and creepmeters. Bull. Seismol. Soc. Am. 2006, 96, S250-S268.

81. Rymer, M.J.; Lisowski, M.; Burford, R.O. Structural explanation for low creep rates on the San Andreas fault near Monarch Peak, central California. Bull. Seismol. Soc. Am. 1984, 74, 925-931.

82. DeLong, S.B.; Hilley, G.E.; Rymer, M.J.; Prentice, C. Fault zone structure from topography: Signatures of en echelon fault slip at Mustang Ridge on the San Andreas fault, Monterey County, California. Tectonics 2010, 29. [CrossRef]

83. Hilley, G.E.; DeLong, S.; Prentice, C.; Blisniuk, K.; Arrowsmith, J.R. Morphologic dating of fault scarps using airborne laser swath mapping (ALSM) data. Geophys. Res. Lett. 2010, 37, L04301.

84. Liu, Z.; Lundgren, P.; Fielding, E.J.; Hensley, S. Imaging fault slip variation along the central San Andreas fault from satellite, airborne InSAR and GPS. Available online: http:/ / abstractsearch.agu.org/meetings / 2011/FM/T43I-06.html (accessed on 17 March 2017).

85. Page, B.M. Evolution and complexities of the transform system in California, USA. Ann. Tecton. 1990, 4, 53-69. 
86. Lawson, A.C.; Reid, H.F. The California Earthquake of April 18, 1906: Report of the State Earthquake Investigation Commission; Carnegie Institution of Washington: Washington, DC, USA, 1908.

87. Wood, H.O.; Buwalda, J.P. Horizontal displacement along the San Andreas fault in the Carrizo Plain, California. Bull. Geol. Soc. Am. 1931, 42, 298-299.

88. Sieh, K.E.; Jahns, R.H. Holocene activity of the San Andreas fault at Wallace creek, California. Geol. Soc. Am. Bull. 1984, 95, 883-896.

89. Wallace, R.E. The San Andreas Fault System, California; US Government Printing Office: Washington, DC, USA, 1990.

90. Hilley, G.E.; Arrowsmith, J.R. Geomorphic response to uplift along the Dragon's Back pressure ridge, Carrizo Plain, California. Geology 2008, 36, 367-370.

91. Akçiz, S.O.; Arrowsmith, J.R. New views on the evolution of the San Andreas fault zone in central California and the Carrizo Plain. Field Guid. 2013, 32, 1-12.

92. Sieh, K.E. Slip along the San Andreas fault associated with the great 1857 earthquake. Bull. Seismol. Soc. Am. 1978, 68, 1421-1448.

93. Zielke, O.; Arrowsmith, J.R.; Ludwig, L.G.; Akçiz, S.O. Slip in the 1857 and earlier large earthquakes along the Carrizo Plain, San Andreas fault. Science 2010, 327, 1119-1122.

94. Zielke, O.; Arrowsmith, J.R.; Ludwig, L.G.; Akciz, S.O. High-Resolution Topography-Derived Offsets along the 1857 Fort Tejon Earthquake Rupture Trace, San Andreas Fault. Bull. Seismol. Soc. Am. 2012, 102, 1135-1154.

95. Akçiz, S.O.; Ludwig, L.G.; Arrowsmith, J.R.; Zielke, O. Century-long average time intervals between earthquake ruptures of the San Andreas fault in the Carrizo Plain, California. Geology 2010, 38, 787-790.

96. Schmalzle, G.; Dixon, T.; Malservisi, R.; Govers, R. Strain accumulation across the Carrizo segment of the San Andreas Fault, California: Impact of laterally varying crustal properties. J. Geophys. Res. Solid Earth 2006, 111, B05403. [CrossRef]

97. Noriega, G.R.; Arrowsmith, J.R.; Grant, L.B.; Young, J.J. Stream channel offset and late Holocene slip rate of the San Andreas fault at the Van Matre ranch site, Carrizo Plain, California. Bull. Seismol. Soc. Am. 2006, 96, 33-47.

98. Salisbury, J.B. Coupling Tectonic Geomorphology and Paleoseismology for Understanding of Earthquake Recurrence. Ph.D. Dissertation, Arizona State University, Tempe, AZ, USA, 2016.

99. Bevis, M.; Hudnut, K.; Sanchez, R.; Toth, C.; Grejner-Brzezinska, D.; Kendrick, E.; Caccamise, D.; Raleigh, D.; Zhou, H.; Shan, S.; et al. The B4 Project: Scanning the San Andreas and San Jacinto Fault Zones. Available online: http:/ / abstractsearch.agu.org/meetings/2005/FM/H34B-01.html (accessed on 17 March 2017).

100. U.S. Geological Survey and California Geological Survey, Quaternary Fault and Fold Database for the United States. Available online: https:/ / earthquake.usgs.gov/hazards/qfaults/ (accessed 17 March 2017).

101. Sims, J.D. Stream channel offset and abandonment and a 200-year average recurrence interval of earthquakes on the San Andreas fault at Phelan Creeks, Carrizo Plain, California. In Proceedings of the Workshop on Paleoseismology, Marshall, CA, USA, 18-22 September 1994; pp. 170-172.

102. Zielke, O.; Klinger, Y.; Arrowsmith, J.R. Fault slip and earthquake recurrence along strike-slip faults-Contributions of high-resolution geomorphic data. Tectonophysics 2015, 638, 43-62.

103. Arrowsmith, J.R.; Zielke, O. Tectonic geomorphology of the San Andreas Fault zone from high resolution topography: An example from the Cholame segment. Geomorphology 2009, 113, 70-81. [CrossRef]

104. Arrowsmith, J.R.; Rhodes, D.D. Original forms and initial modifications of the Galway Lake Road scarp formed along the Emerson fault during the 28 June 1992 Landers, California, earthquake. Bull. Seismol. Soc. Am. 1994, 84, 511-527.

105. Haddad, D.E.; Akçiz, S.O.; Arrowsmith, J.R.; Rhodes, D.D.; Oldow, J.S.; Zielke, O.; Toké, N.A.; Haddad, A.G.; Mauer, J.; Shilpakar, P. Applications of airborne and terrestrial laser scanning to paleoseismology. Geosphere 2012, 8, 771-786.

106. Landers Surface Rupture Terrestrial Laser Scanning Dataset. Available online: https://doi.org/10.5069/ G91Z4298 (accessed on 17 March 2017).

107. Listing of /v1/AUTH_opentopography/hosted_data/SfM_GalwayLakeRd_1.23.2014/. Available online: https://cloud.sdsc.edu/v1/AUTH_opentopography/hosted_data/SfM_GalwayLakeRd_1.23.2014/ (accessed on 17 March 2017).

108. Rubin, C.M.; Sieh, K. Long dormancy, low slip rate, and similar slip-per-event for the Emerson fault, eastern California shear zone. J. Geophys. Res. Solid Earth 1997, 102, 15319-15333.

109. Ludwig, L.G.; Brune, J.N.; Anooshehpoor, A.; Purvance, M.D.; Brune, R.J.; Lozos, J.C. Reconciling precariously balanced rocks (PBRs) with large earthquakes on the San Andreas fault system. Seismol. Res. Lett. 2015. [CrossRef] 
110. Thatcher, W.; Savage, J.C.; Simpson, R.W. The Eastern California Shear Zone as the northward extension of the southern San Andreas fault. J. Geophys. Res. Solid Earth 2016. [CrossRef]

111. Hauksson, E.; Stock, J.; Hutton, K.; Yang, W.; Vidal-Villegas, J.A.; Kanamori, H. The 2010 Mw 7.2 El Mayor-Cucapah Earthquake Sequence, Baja California, Mexico and Southernmost California, USA: Active Seismotectonics along the Mexican Pacific Margin. Pure Appl. Geophys. 2011, 168, 1255-1277.

112. Rymer, M.J.; Treiman, J.A.; Kendrick, K.J.; Lienkaemper, J.J.; Weldon, R.J.; Bilham, R.; Wei, M.; Fielding, E.J.; Hernandez, J.L.; Olson, B.P. Triggered Surface Slips in Southern California Associated with the 2010 El Mayor-Cucapah, Baja California, Mexico, Earthquake; US Geological Survey: Reston, VA, USA, 2011.

113. Gonzalez-Ortega, A.; Fialko, Y.; Sandwell, D.; Alejandro Nava-Pichardo, F.; Fletcher, J.; Gonzalez-Garcia, J.; Lipovsky, B.; Floyd, M.; Funning, G. El Mayor-Cucapah (Mw 7.2) earthquake: Early near-field postseismic deformation from InSAR and GPS observations. J. Geophys. Res. Solid Earth 2014, 119, 1482-1497.

114. Hauksson, E.; Stock, J.; Bilham, R.; Boese, M.; Chen, X.; Fielding, E.J.; Galetzka, J.; Hudnut, K.W.; Hutton, K.; Jones, L.M. Report on the August 2012 Brawley earthquake swarm in Imperial Valley, Southern California. Seismol. Res. Lett. 2013, 84, 177-189.

115. Lohman, R.B.; McGuire, J.J. Earthquake swarms driven by aseismic creep in the Salton Trough, California. J. Geophys. Res. Solid Earth 2007, 112, B04405.

116. Wei, S.; Avouac, J.-P.; Hudnut, K.W.; Donnellan, A.; Parker, J.W.; Graves, R.W.; Helmberger, D.; Fielding, E.; Liu, Z.; Cappa, F. The 2012 Brawley swarm triggered by injection-induced aseismic slip. Earth Planet. Sci. Lett. 2015, 422, 115-125.

117. Sieh, K.; Williams, P.L. Behavior of the southernmost San Andreas fault during the past 300 years. J. Geophys. Res. 1990. [CrossRef]

118. Rymer, M.J. Triggered surface slips in the Coachella Valley area associated with the 1992 Joshua Tree and Landers, California, earthquakes. Bull. Seismol. Soc. Am. 2000, 90, 832-848. [CrossRef]

119. Vincent, P. Aseismic slip events along the southern San Andreas fault system captured by radar interferometry. In Proceedings of the 3rd Conference on Tectonic Problems of the San Andreas Faul System, Stanford, CA, USA, 6-8 September 2000; Bokelmann, G., Kovach, R.L., Eds.; 2000; p. 193.

120. Behr, J.; Bilham, R.; Bodin, P.; Gross, S. Eureka peak fault afterslip following the 28 June 1992 Landers earthquake. Bull. Seismol. Soc. Am. 1994, 84, 826-834.

121. DeLong, S.B.; Prentice, C.S.; Hilley, G.E.; Ebert, Y. Multitemporal ALSM change detection, sediment delivery, and process mapping at an active earthflow. Earth Surf. Process. Landf. 2012, 37, 262-272. [CrossRef]

122. Rundle, P.B.; Rundle, J.B.; Tiampo, K.F.; Donnellan, A.; Turcotte, D.L. Virtual California: Fault model, frictional parameters, applications. Pure Appl. Geophys. 2006, 163, 1819-1846. [CrossRef]

123. Grieve, S.W.; Mudd, S.M.; Milodowski, D.T.; Clubb, F.J.; Furbish, D.J. How does grid-resolution modulate the topographic expression of geomorphic processes? Earth Surf. Dyn. 2016, 4, 627-653.

124. Hurst, M.D.; Mudd, S.M.; Attal, M.; Hilley, G. Hillslopes record the growth and decay of landscapes. Science 2013, 341, 868-871. [CrossRef]

125. Donnellan, A.; Lyzenga, G.A. GPS observations of fault afterslip and upper crustal deformation following the Northridge earthquake. J. Geophys. Res. Solid Earth 1998, 103, 21285-21297.

126. Azúa, B.M.; DeMets, C.; Masterlark, T. Strong interseismic coupling, fault afterslip, and viscoelastic flow before and after the Oct. 9, 1995 Colima-Jalisco earthquake: Continuous GPS measurements from Colima, Mexico. Geophys. Res. Lett. 2002, 29. [CrossRef]

127. Grant, L.B.; Donnellan, A. 1855 and 1991 surveys of the San Andreas fault: Implications for fault mechanics. Bull. Seismol. Soc. Am. 1994, 84, 241-246.

128. Davis, J.L.; Kellogg, L.H.; Arrowsmith, J.R.; Buffett, B.A.; Constable, C.G.; Donnellan, A.; Ivins, E.R.; Mattioli, G.S.; Owen, S.E.; Pritchard, M.E.; et al. Challenges and Opportunities for Research in ESI (CORE). Available online: https://smd-prod.s3.amazonaws.com/science-green/s3fs-public/atoms/files/CORE2016.pdf (accessed on 14 March 2017).

(C) 2017 by the authors. Licensee MDPI, Basel, Switzerland. This article is an open access article distributed under the terms and conditions of the Creative Commons Attribution (CC BY) license (http:/ / creativecommons.org/licenses/by/4.0/). 